\title{
PPARs in liver physiology
}

Alexandre Berthier ${ }^{*, 1}$, Manuel Johanns ${ }^{*, 1}$, Francesco Paolo Zummo*,1, Philippe Lefebvre ${ }^{1, \$}$, Bart Staels ${ }^{1, \$}$

${ }^{1}$ Univ. Lille, Inserm, CHU Lille, Institut Pasteur de Lille, U1011- EGID, F-59000 Lille, France

${ }^{*}$ Contributed equally to this work

\$Corresponding authors

bart.staels@pasteur-lille.fr

Inserm UMR1011, Institut Pasteur de Lille

1 rue du Pr Calmette, F-59000 Lille

or

philippe-claude.lefebvre@inserm.fr

Inserm UMR1011, Bldg J\&K, Faculté de Médecine de Lille

Blvd du Pr Leclerc

59000, Lille, France 
Highlights

- PPAR isotype expression is specific for distinct liver cell types

- The expression of PPARs is spatially zonated across the liver lobule

- Hepatic PPAR $\alpha$ and PPAR $\beta / \delta$ display circadian rhythmicity

- PPAR expression presents a sexual dimorphism

- PPAR-mediated gene expression regulation is in some instances species-dependent 


\section{Abstract $(<150$ words $)$}

Peroxisome proliferator-activated receptors (PPARs) are nuclear receptors and transcriptional modulators with crucial functions in hepatic and whole-body energy homeostasis. Besides their well-documented roles in lipid and glucose metabolism, emerging evidence also implicate PPARs in the control of other processes such as inflammatory responses. Recent technological advances, such as single-cell RNA sequencing, have allowed to unravel an unexpected complexity in the regulation of PPAR expression, activity and downstream signaling. Here we provide an overview of the latest advances in the study of PPARs in liver physiology, with a specific focus on formerly neglected aspects of PPAR regulation, such as tissular zonation, cellular heterogeneity, circadian rhythms, sexual dimorphism and species-specific features. 


\section{INTRODUCTION}

The liver is a multifunctional organ with key roles in metabolic homeostasis, immune defense and inflammatory response, storage and clearance of bioactive molecules, endo- and xenobiotic detoxification and regulation of blood clotting. Liver activities are regulated both in time and space: circadian rhythms and food intake, together with a highly structurally and functionally organized liver structure, a compartmentalization of functions between liver cell types and sexual dimorphism all contribute to liver physiology. Peroxisome proliferatoractivated receptors (PPARs) regulate multiple hepatic activities: while some of their roles are well-described in the literature, new insights have been revealed in recent years. Given their central roles in liver physiology and their ability to be regulated by small lipophilic molecules, a property which prompted many (pre)clinical trials aiming to target PPARs to ease liver injuries, the investigation of their role in liver physiology is of great interest [1,2].

PPARs are transcription factors (TFs) of the nuclear receptor superfamily. There are three isotypes coded by distinct genes: PPARA (NR1C1), PPARD (NR1C2) and PPARG (NR1C3). Like all class III nuclear receptors, PPARs generally function as ligand-controlled transactivators, inducing the expression of target genes after agonist binding. Briefly, PPARs form heterodimers with retinoid $X$ receptors ( $R X R \alpha, R X R \beta, R X R Y)$ and bind to DNA on specific repeated hexanucleotidic sequences with the identified consensus sequence AGGTCA, called PPAR response elements (PPREs). In the absence of a ligand, or when bound to an antagonist, this protein complex interacts with a co-repressor, such as the nuclear receptor corepressor (NCoR), silencing mediator of retinoic acid and thyroid hormone receptor (SMRT) or G-protein suppressor 2 (GPS2). These co-repressors, by recruiting Histone deacetylase 3 (HDAC3) to DNA, affect chromatin structure to block PPAR target gene expression [3]. Even though all PPAR family members are sensitive to unsaturated fatty acids (FAs), the PPAR isotypes exhibit high specificity and selectivity for ligand binding [1,2]. Interaction of an agonist with the C-terminal PPAR ligand binding domain induces a conformational modification which triggers the release of the co-repressor complex and allows the docking of co-activators, such

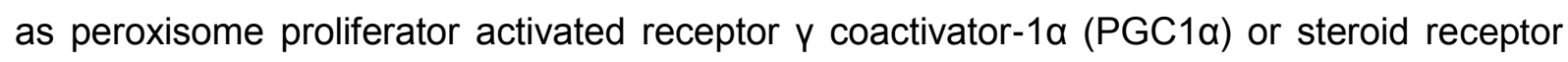
coactivator-1 (SRC1) [4]. In addition to this classical mechanism of action, PPARs can also act as transrepressors of genes mainly involved in proinflammatory pathways, by interacting with other TFs in a PPRE-independent manner [5,6]. Hepatic PPAR activity is mainly determined by i) agonist availability, ii) their relative expression levels across cell types, iii) the cell-specific epigenomic and transcriptional machinery, iv) the nutritional status, v) circadian rhythms and vi) sexual dimorphism [7,8]. All these aspects will be discussed in this review.

In the liver, PPARa is the predominant isotype. PPAR $\beta / \delta$ is mostly expressed in tissues controlling lipid metabolism, such as skeletal muscle, adipose tissues and macrophages, but is also present in the liver. Three mRNA splice variants coding for isoforms of PPARY $(\mathrm{Y} 1, \mathrm{Y} 2$, 
Y3) can be produced from the $N R 1 C 3$ gene in a tissue-specific manner: Whereas PPARY1 is ubiquitously expressed, PPARY2, the longest isotype, is expressed in both adipose tissues and liver and PPARY3 is expressed mainly in colon and adipose tissue [9,10]. Proteins produced from the $\mathrm{Y} 1$ and $\mathrm{Y} 3 \mathrm{mRNAs}$ are identical, while the PPARY2 protein harbors 30 (in mouse) or 28 (in human and monkey) extra amino acids at its $\mathrm{N}$-terminus $[11,12]$.

\section{GENERAL PPAR FUNCTIONS}

Broadly speaking, the systemic activation of PPARa leads to energy dissipation by promoting fatty acid oxidation (FAO) and thermogenesis, whereas PPARy favors energy storage mainly through increased lipogenesis and adipogenesis. PPARy activation improves glucose metabolism by enhancing insulin-induced suppression of white adipose tissue (WAT) lipolysis. Although less studied, the PPAR $\beta / \delta$ activation process induces a combination of the metabolic effects controlled by other PPAR isotypes, namely by promoting expenditure/dissipation, FAO and increasing insulin sensitivity [13].

The role of hepatic PPARa in the adaptive response to feeding/fasting transitions by regulating FA, lipid and lipoprotein metabolism is well described (Figure 1). PPARa plays a crucial role in maintaining metabolic flexibility by adapting fuel (FA/lipids in particular) utilization and storage to the nutritional state. During the fasting period, hepatic PPARa promotes uptake and utilization (mainly via oxidation) of circulating FAs, the majority of which deriving from WAT lipolysis. Direct PPARa targets include FA transport proteins such as CD36, SLC27A1, FABP4, transferases such as $C P T 1 A$, and fatty acyl-CoA dehydrogenases to increase mitochondrial FAO and eventually ketogenesis [14]. PPARa is also required for the induction of the hepatokine FGF21 in response to fasting as well as in the early post-prandial phase in a crosstalk with the carbohydrate-responsive element-binding protein (ChREBP), hence coordinating the systemic gluco-regulatory and insulin-sensitizing effects of FGF21 in mice [15]. PPAR $\alpha$ further participates in maintaining the hepatic energy balance by inducing autophagy (lipophagy in particular) in the fasted state, in coordination with the nuclear bile acid receptor FXR which suppresses autophagy in the fed state [16,17]. During the feeding/active phase, PPARa induces hepatic lipogenesis to stockpile fatty acids as triglyceride fuel stores, notably by increasing the expression of citrate carrier (SLC25A1) which shuttles acetyl-CoA from mitochondria to the cytosol for FA synthesis [18]. PPARa also increases the maturation of the transcription factor SREBP1C from its $120 \mathrm{kDa}$ precursor protein, thereby indirectly increasing expression of lipogenic target genes [19]. By enhancing hepatic FA uptake and oxidation and altering expression of apolipoproteins, while simultaneously inducing lipoprotein lipase activity, PPARa activation leads to an improved plasma lipid balance as indicated by lower (V)LDLand higher HDL-cholesterol [7]. Targeted deletion of hepatic Ppara in mice resulted in 
enhanced liver steatosis particularly in the fasted state, due to impaired oxidation of FAs derived from WAT lipolysis [14], even though extrahepatic PPAR $\alpha$ partly compensates by increasing FAO in other tissues, such as heart and skeletal muscle [20].

PPARy also controls FA uptake and lipogenesis through induction of genes such as $C D 36$ and $F A B P 1$, and acts in cooperation with insulin-dependent mTORC1 signaling [21] (Figure 1). WAT PPARY activity indirectly improves insulin sensitivity in peripheral organs and the liver by triggering WAT differentiation and fat storage, which in turn funnels lipids and FAs from liver and skeletal muscle to WAT [7]. In the long term, this 'lipid stealing effect' is thought to reduce lipotoxicity, otherwise impairing insulin signaling, and thus improving the hepatic response to insulin and decreasing excessive hepatic glucose production. Adenovirusmediated overexpression of PPARY2 in hepatocytes increased hepatosteatosis, while hepatocyte-specific disruption of the Pparg gene decreased liver steatosis in ob/ob mice $[22,23]$. Although activation of PPARy is steatogenic in the liver, treating diet-induced or genetically obese mice with PPARY ligands decreased hepatic triglyceride (TG) content $[24,25]$. These distinct effects stem, at least in part, from enhanced synthesis of adiponectin in white adipose tissue in the case of systemic PPARY activation [26]. Circulating adiponectin could increase glucose uptake and FAO in hepatocytes by activating AMPK and generating PPARa ligands (see below), thereby improving systemic insulin sensitivity and reducing liver steatosis [27].

Liver-specific knockout of Pparg expectedly resulted in a decreased expression of genes associated with FA uptake and lipogenesis in liver. In lipoatrophic AZIP mice and despite reduced hepatic steatosis, systemic insulin resistance, hyperlipidemia and adiposity were worsened when Pparg was deleted in liver, indicating a protective role of PPARy from peripheral insulin resistance under lipoatrophic conditions [25].

Hepatic PPARß/ס's functions are less characterized than those of the other isotypes, as its expression is much higher in skeletal muscle than in liver. However, the use of selective agonists and liver-restricted Ppard gene knockout in mice revealed its significant contribution to metabolic regulation in liver (Figure 1). Like PPARa, PPAR $\beta / \delta$ activation increases hepatic FAO [13]. In addition, PPAR $\beta / \delta$ induces the expression and the ligand-mediated activation of PPARa, creating a synergistic relationship between these 2 isotypes [28]. PPAR $\beta / \delta$ also induces expression of APO-All and PLTP to increase plasma HDL $[29,30]$. Like PPARY, PPAR $\beta / \delta$ improves insulin responsiveness and glucose metabolism in liver yet by different mechanisms: liver PPAR $\beta / \delta$ agonism or overexpression redirect hepatic glucose towards the pentose phosphate pathway and glycogen synthesis rather than towards glucose output [31,32]. A very interesting study using liver-restricted Ppard-knockout mice [33] revealed a cross-talk between hepatic PPAR $\beta / \delta$ and skeletal muscle FA metabolism. Liver PPAR $/ \delta$ driven synthesis of 18:0/18:1 phosphatidylcholine was found to be the messenger of this inter- 
organ communication, while skeletal muscle PPARa was the receiver. In mice lacking hepatic Ppard, there was almost no induction of hepatic Acc1/2, Fasn, Acads and of skeletal muscle FA uptake during the dark cycle (active phase of rodents).

In addition to their central role in regulating energy metabolism, all three PPAR isotypes also have anti-inflammatory properties by reducing the expression of pro-inflammatory mediators such as TNF $\alpha$, IL1 and IL6, via direct interaction or functional interference with proinflammatory transcription factors such as NF-KB [34]. This feature is interesting for drug targeting, as a systemic low-grade 'meta'-inflammation is a hallmark of the metabolic syndrome, obesity and steatohepatitis. However, the matter exceeds the scope of the present review and was recently reviewed in a more detailed fashion elsewhere [35]. Interestingly, there is a bidirectional relationship between hepatic inflammation and PPARs, as proinflammatory cytokines, such as IL $1 \beta$, secreted by macrophages in response to lipid overload, decrease expression of PPARa and of its target genes involved in FAO [36].

\section{SPATIAL FEATURES OF PPAR ACTIVITY}

\section{a) Liver cell types}

The liver is structured as a lobule, a roughly hexagonal structure where cords of hepatocytes held together by tight junctions are separated by sinusoids. These highly permeable small vessels radiate from a single central vein to the vertices of the hexagon where they reach the portal triad, constituted of branches of the hepatic artery and hepatic portal vein, together with bile ducts. Although microscopically more difficult to visualize than the lobule, the liver architecture is physiologically better represented by the acinus, which follows the blood stream: in this representation, lines of hepatocytes are organized along an axis defined by hepatic arterioles and portal venules. This architecture defines 3 zones, with zone 1 being irrigated by the portal venules with oxygenated and nutrient-loaded blood. Zone 3 is in close contact with the central vein and in contrast to zone 1 , is highly sensitive to hypoxic conditions. Zone 2 is the intermediate zone. This physical zonation is reflected at the functional level (Figure 2) [37].

Liver functions are performed by several highly specialized cell populations organized in functional sinusoidal units. The liver parenchyma consists of a complex network of hepatocytes, epithelial cells which are responsible for the majority of liver functions ranging from maintaining systemic metabolic homeostasis and regulation of nutrient levels in blood to extraction and metabolism of xenobiotics and systemic waste products, bile synthesis and nutrient storage [38]. Hepatic sinusoids are lined by a thin endothelium that lacks a basal lamina and is made of liver sinusoidal endothelial cells (LSEC). This endothelial lining is essential to regulate liver blood pressure via nitric oxide [39], has a strong endocytic capacity 
and is highly fenestrated to allow easy exchange of metabolites, solutes and waste products between blood and hepatocytes through the space of Disse [40,41]. Kupffer cells (KC), which are the largest population of tissue macrophages, are found within or below the sinusoidal endothelium and extend their processes into sinusoids. KCs contribute to maintaining tissue homeostasis and neutralizing antigens and microbes arriving from the gastrointestinal tract via endocytosis. KCs dynamically contribute to inflammation and wound healing responses by acquiring pro- or anti-inflammatory phenotypes [42]. In the space of Disse, together with KCs, are also localized hepatic stellate cells (HSC). Under physiological conditions, HSCs are quiescent cells, storing retinyl esters in cytoplasmic lipid droplets and contributing to liver homeostasis. Upon liver injury, HSCs undergo drastic changes, transdifferentiating into highly proliferative myofibroblasts, which replace damaged hepatocytes with scar tissue through extracellular matrix (ECM) reorganization. This scarring process is essential for tissue repair once the injury is resolved, but can result in hepatic fibrosis in case of chronic injury [43,44]. The biliary tree is formed by a heterogeneous epithelial population of cholangiocytes $(\mathrm{CH})$. In large ducts, $\mathrm{CHs}$ are normally cuboidal and larger than those in small intrahepatic ductules. Functionally, large $\mathrm{CHs}$ are involved in bile secretion, while small $\mathrm{CHs}$ show high proliferation and functional plasticity [45].

Apart from these main and best characterized liver cell populations, other resident or infiltrating cell types include portal fibroblasts, mesothelial cells, natural killer cells, dendritic cells, bone marrow-derived macrophages, neutrophils, T lymphocytes, bone marrow-derived myofibroblasts and others [46-49]. As their roles have been mostly studied in pathological conditions, they will not be discussed further in this review.

The expression and functions of the PPAR family members in the different liver cell populations are still to be fully unveiled. Studies on transcript levels and responses to selective agonists, and more recently omics and single-cell approaches indicate that PPAR is the major hepatic isotype and is mainly expressed in hepatocytes, with low expression levels in nonparenchymal cells both in human and mouse (Figure 2). PPARy expression in mouse is higher in hepatocytes and HSCs than in KCs and LSECs, although there could be differences in PPARY1 and PPARY2 isoform levels, at least in female mice (Figure 2). In humans, PPARy is more expressed in endothelial and mesenchymal cells. PPAR $\beta / \delta$ is mainly expressed in murine CHs, HSC and LSECs [50-52] although recent human single-cell data indicate that it is expressed at low levels in all liver cells $[53,54]$.

Besides the well-documented metabolic roles of PPARs established from whole liver studies, which generally characterize their functions in hepatocytes, complementary functions of all PPAR isotypes have been described in other liver cell types. For instance, PPARa is required in macrophages for agonist-induced reduction of the inflammatory cytokines IL-15 and IL-18, but its macrophage-specific deletion affects neither hepatic lipid metabolism, nor 
cell proliferation or expression of DNA damage and repair-related genes [55]. Similar results were obtained in another study comparing the phenotypes of Pparg gene knockout mice restricted to hepatocytes or macrophages [24]. PPARy was shown to favor anti-inflammatory polarization of $\mathrm{KCs}$ in response to lipids and agonist treatment and to alleviate steatosisinduced local inflammation [56]. In response to the Th2 cytokine IL-4, PPAR $\beta / \delta$ favors an antiinflammatory phenotype in KCs and adipose tissue macrophages in lean mice and improved systemic insulin responsiveness [57]. Interestingly, another study detected higher Ppard expression in KCs and HSCs compared to hepatocytes and revealed a strong anti-fibrotic potential of the PPAR $/ \delta$ agonist KD3010, without altering macrophage polarization or HSC activation [58]. In HSCs, selective agonism of the major isotype PPARY (mostly PPARY1, [59]) with thiazolidinediones (TZDs) decreased cell activation, collagen(I) production, and reduced proliferation and inflammatory chemotaxis as encountered in NAFLD [60,61]. Pparg expression is lost during HSC myofibroblastic transdifferentiation, while treatment with PPARY agonists or ectopic Pparg overexpression allows maintenance, or reversion to, a quiescent lipocyte-like phenotype through a process analogous to adipogenesis [62].

Liver cell-specific PPAR functions are also dependent on the expression of their obligatory heterodimerization partners, the Retinoid X Receptors (RXRs). Several studies report that RXRa is mostly expressed in hepatocytes and that RXRY expression levels is low in all liver cell types. Data on RXR $\beta$ are less consensual and the determination of its expression level within the liver needs further investigation [50,51,53,63]. Of note, variation in the $\mathrm{RXR} \alpha / \mathrm{RXR} \beta$ ratio per se could regulate PPAR activities, as shown for PPARY [64].

A complete understanding of the cell-specific PPAR functions can be considered as one of the next challenges in the study of these NRs. Studies on cell (sub)populations are nevertheless experimentally challenging, whether they are based on organ dissociation and cell sorting, or on in situ detection of transcripts [65].

\section{b) Liver zonation}

In the sinusoid, mixed arterial and venous blood flows from the hepatic artery and the hepatic portal vein, which drains the blood from the capillary system of the intestine, spleen, pancreas, omentum and gallbladder, to the center of the lobule. Central veins then feed into the hepatic vein that drains the tissue. The high permeability of the sinusoids regulates blood nutrient and hormone levels, clearance of foreign bodies and toxic compounds while supplying the liver with nutrients and oxygen [66]. Blood composition therefore changes when flowing from the portal tracts (periportal area) to the central vein (pericentral area). The resulting gradients of oxygen, nutrients and hormones, together with morphogenetic factors, determine important functional differences between the periportal $(P P)$ and pericentral $(P C)$ areas, a 
phenomenon called zonation (Figure 2). Zonation is essential for liver organization and regulation and is a highly dynamic process, influenced by nutrition, hormones, drugs and circadian rhythm [67]. Interestingly, while it has been mainly characterized in the liver, new data suggest that zonation may also occur in other organs like the kidney [68], intestine [69] and brain [70]. Liver zonation is mainly determined by oxygen availability and the $\mathrm{Wnt} / \beta$ catenin signaling pathway [71-73].

Liver zonation affects both the parenchyma and the stroma $[71,74,75]$. In LSECs, for example, $>30 \%$ of genes are expressed in a zonated fashion, with pericentral LSECs being responsible for the expression of the pericentral morphogen Wnt $[53,63]$. LSEC zonation results in differences in fenestrae diameter and number [76]. Zonation also affects HSCs in healthy and injured liver. In particular, it was shown that the pericentral HSCs are the main source of collagen in a mouse model of centrilobular fibrosis [77]. Even though it was hypothesized that KCs might be spatially heterogeneous, and different subpopulations of cells have indeed been identified, whether this is due to a true zonation process remains to be further investigated $[53,78,79]$.

The spatial division of hepatic functions was first identified, and better characterized, by studying the metabolic activities across the parenchyma [77]. Single-cell transcriptomics revealed that up to $50 \%$ of the expressed liver genes are non-randomly spatially zonated [72]. Recently, portal-to-central differences in several metabolic pathways involved not only in carbohydrate, FA and amino acid metabolism but also in detoxification were also shown in hepatocytes using quantitative proteomics [80]. The highly oxygenated and nutrient-exposed periportal hepatocytes (PPH) are involved in energy-demanding tasks like gluconeogenesis, FA $\beta$-oxidation, cholesterol and urea synthesis and plasma protein production. Accordingly, $\mathrm{PPH}$ express higher levels of key regulatory enzymes of gluconeogenesis, such as PhosphoEnolPyruvate CarboxyKinase (PEPCK), the bi-functional PhosphoFructoKinase-2 (FBP2/PFK2), as well as GlucoKinase (GK) and the rate-limiting enzyme of cholesterol synthesis 3-Hydroxy-3-MethylGlutaryl-CoA Reductase (HMGCR). Pericentral hepatocyte $(\mathrm{PCH})$ preferred activities are glucose uptake, glycolysis, lipogenesis, xenobiotic metabolism, bile acid biosynthesis and glutamine synthesis [75,80,81]. Whether PPARs expression and/or functions are zonated has not yet been fully explored but, interestingly, recent single-cell data on hepatocytes suggest a zonation of PPAR signaling in the mouse liver [72].

As described above, PPARa promotes FAO during the fasting/resting phase, but induces lipogenesis during the feeding/active phase [14,18]. In single-cell RNAseq analysis of hepatocytes, Ppara expression was found to be slightly higher in pericentral regions. Interestingly, PPARa target genes such as Pdk4, Acox1, Vnn1, Cd36, Fatbp4 and Slc27a1, showed an expression pattern similar to Ppara. Recently, another study from the same group combined transcriptomics and proteomics of zonated hepatocytes. These data confirmed the 
preferential gene expression in pericentral areas of Ppara and of its targets Cpt1, Acox1 and $V n n 1$, for which high pericentral protein levels were also observed $[72,80,82]$. Although this result suggests that Ppara expression is lower where FAO occurs, further studies are required to understand if the zonated expression of Ppara varies according to nutritional status, whether PPARa activities depend on ligand gradients or post-transcriptional modifications and if the balance between Ppara expression and oxygen gradient influences the FAO rate. A link between PPARa and oxygen concentration was nevertheless unveiled. Under steatotic conditions, the increased expression of hypoxia-induced factor $2 \alpha$ (HIF-2 $\alpha$ ) suppresses PPAR a expression and thus FAO in the liver [83]. Of note, PPARa mediates cardiac metabolic remodeling in response to hypoxia [84]. A correlation between PPAR $\alpha$ and increased tolerance to environmental, high-altitude hypoxia in Tibetan population has been reported [85]. PPARY general functions are to regulate FA uptake and lipogenesis [7]. In accordance with hepatocyte metabolic zonation in mice, Pparg exhibited a striking centrilobular expression together with its target gene $L p l$, whereas expression of its coactivator Pgc1a (and to a lesser extent Pgc1 $\beta$ ) were clearly periportal [72].

Another example of liver division of labor is bile acid synthesis. Hepatocytes are polarized and secrete bile acids (BAs) from the apical surface into a network of biliary canaliculi located between the two cords of cells on the contralateral side of the sinusoids. Canaliculi reach the lobular periphery where they form the intralobular ductules (or canals of Hering) which then enter bile ductules and ducts, flowing toward the gallbladder, common bile duct and intestine [86]. Bile acids are produced in pericentral hepatocytes from cholesterol. By deconvoluting BA-metabolizing Cyp450 gene expression in zonated, adjacent hepatocytes, Halpern and colleagues showed that the Cyp7a1, Cyp8b1, Cyp27a1, Hsd3b7 and Baat genes exhibit a spatial order of expression that matches the position in the BA biosynthesis cascade, which is a remarkable strategy to limit BA accumulation and toxicity in a single hepatocyte [72]. Interestingly, PPARa regulates bile acid metabolism and excretion, as shown in rat hepatocytes and in whole-body and liver-specific Ppara knock-out mice [87-89]. These activities may contribute to the beneficial effects of agonists targeting PPARa and/or PPARd in primary biliary cholangitis (PBC) [90-94] (see Table1). Whether and how PPARa participates in zonated BA homeostasis remains to be established.

It has been proposed that liver zonation and hepatocyte renewal are also linked, by identifying a population of proliferating and self-renewing pericentral hepatocytes regulated by WNT signaling [95]. A connection between zonation and liver regeneration is also suggested by the fact that bile acid signaling can promote liver growth in an FXR-dependent manner [96]. PPAR $\alpha$ regulates bile acid synthesis [87] and affects hepatocyte proliferation [55] but it remains to be unveiled if this is affected by PPAR $\alpha$ zonated expression. It was nevertheless suggested that PPARa regulates the expression of Mfsd2a in periportal hepatocytes, which is essential 
for their expansion and for liver repair. Intriguingly, Mfsd2a encodes a transporter for the $\omega 3$ fatty acid docosahexaenoic acid (DHA), a natural agonist of both PPARa and RXRs [97-100].

Ppard, Rxra and Rxrb are expressed equally across the lobule. Accordingly, PPAR $\beta / \delta$ putative targets ApoA2, Lipin1, Fgf21 and Vldr expression was also found unchanged across the lobule [7,72]. Interestingly, while data on human liver suggest that PPAR expression is not zonated, the methylation status of PPARA, PPARGC1 $\alpha, P P A R G C 1 \beta, R X R A, R X R B, C P T 1 a$, and $A C O X 1$ genes vary along the sinusoid, supporting the importance of epigenomic analyses in the characterization of PPAR activities [101].

In summary, recent scRNA-seq data suggest that Ppara and Pparg are expressed in a zonated manner, even though the relation between zonation and PPAR activity and functions has not yet been thoroughly investigated and available data were obtained from a single timepoint.

\section{TEMPORAL COMPONENTS OF PPAR REGULATION}

\section{a) Hepatic rhythmic biology - feeding state \& the circadian clock}

In addition to spatial zonation and intrinsic heterogeneity among hepatic cell populations, all major hepatic functions are also timed following a circadian rhythmicity and according to the nutritional status. These two regulatory mechanisms are strongly interconnected in order to adapt energy expenditure, production and storage to supply needs along the day/night cycle, and food intake is a dominant "Zeitgeber" for the liver [102]. PPARs are central players in the crosstalk between energy metabolism and circadian rhythms, as they all sense and anticipate changes in the nutritional state and functionally adapt metabolic pathways accordingly.

Under physiological conditions, during the active phase (fed state), the liver needs to direct its metabolic activities towards energy storage, mainly glycogenesis and lipogenesis from dietary glucose and lipids. During the resting phase (fasted state), the liver supplies the body with glucose via glycogenolysis and gluconeogenesis and subsequently with ketone bodies from ketogenesis. In line with this, expression and activity of rate-limiting enzymes controlling liver functions exhibit rhythmic daily variations, e.g. PEPCK and G6Pase in gluconeogenesis, ACC in lipogenesis, several CYP450s (Cyp7a1, Cyp8b1, Cyp39a1...) in cholesterol and bile acid synthesis. Besides pathways involved in energy metabolism, hepatic detoxification reactions and global protein synthesis also vary considerably over daytime [103]. Feeding behavior is naturally synchronized with the level of physical activity and nutrient accessibility to maintain metabolic homeostasis. The expression and activity of circadian proteins are determined by two distinct but complementary and tightly interconnected inputs. On the one 
hand, an intrinsic cycling related to the circadian clock machinery, exemplified by the fact that mice kept in constant darkness still exhibit clock cycling in the liver [104] and, on the other hand, the dietary status i.e. the feeding/fasting behavior. Indeed, shifting feeding of mice to the rest phase also progressively shifts the hepatic clock by $\sim 12$ hours [105]. This is particularly true for the liver, where the molecular clock can be "entrained" by timed feeding-fasting cycles. Perturbations in circadian clock function result in worsened metabolic parameters [106]. Disturbed circadian rhythms in livers of clock-mutant mice can be restored by limiting feeding to the active phase [107] and diet-induced hepatic steatosis can be prevented by timerestricted feeding without caloric restriction, at least in mice [108].

PPARs and the circadian clock genes are interconnected at many levels, reciprocally regulating each other (see next section). In addition to intrinsic clock cycling, food intake and thus nutrient/ligand availability constitute the dominant input cues for regulating PPAR activity over daytime. Perhaps the major regulator of PPAR activity is the abundance of ligands, namely long-chain FAs and derivates such as eicosanoids, whose concentrations in plasma and liver vary considerably over daytime both in mice and humans [109]. One such ligand is the diurnally-regulated gut metabolite oleoylethanolamide (OEA). OEA is synthesized in the small intestine during the rest period and suppresses food intake in a PPARa-dependent manner, thus acting as a nutritional feedback signal to the clock and subsequent regulation of circadian metabolism and behavior [110]. Hepatic FA concentrations are determined by feeding periods, via nutritional uptake of FAs produced by adipose tissue lipolysis in fasting conditions and by hepatic de novo lipogenesis in the fed state. Given the fact that PPARs are crucial regulators of lipid metabolism, this allows the creation of regulatory feedback loops. Interestingly, a recent study identified a link between the gut microbiome, hepatic PPAR signaling and clock cycling, that conveys nutritional challenges as circadian outputs in liver [111]. Using fecal transplants, the study revealed that the gut microbiota drives hepatic PPARYmediated activation of newly oscillatory transcriptional programs in the liver in response to a high-fat diet and, conversely, that treatment with antibiotics prevented PPARy-driven transcription activity in the liver.

\section{b) Molecular crosstalk between PPARs and the clock machinery}

The molecular clock is a cell-autonomous feedback system that allows rhythmic cycling of mRNA and protein expression in a circadian ( 24h) manner. The positive arm of the core clock is composed of brain and muscle aryl hydrocarbon receptor-like protein 1 (BMAL1, Arntlgene) and circadian locomotor output cycles protein kaput (CLOCK, Clock gene) acting together as a heterodimeric transactivator. BMAL1-CLOCK promotes the expression of the core negative arm consisting of period circadian protein homolog (PER1/2, Per genes) and cryptochrome 
(CRY1/2/3, Cry genes) which retro-inhibits CLOCK-BMAL1 activity. Additional feedback loops involve the "reverse gene of thyroid receptors" (REV-ERB $\alpha / \beta, N r 1 d 1 / 2$ genes) and the retinoid acid receptor-related orphan receptors (ROR $\alpha / \beta / \gamma, N r 1 f 1 / 2 / 3$ genes) which repress or induce BMAL1 expression, respectively. When studying circadian gene expression and physiology in different species, it is important to note that rodents are essentially nocturnal animals while humans are diurnal, thus their circadian rhythms are in opposite phase. Time indications are generally given as ZT (Zeitgeber time, 0-24 hours) with ZTO indicating the start of the day/light phase (i.e. the resting period for mice) under standard housing conditions.

All three PPAR isotypes exhibit some daily rhythmic expression patterns in peripheral tissues and their activities as transactivators vary in a circadian manner (Figure 3). It has been known for more than 20 years that, in murine liver, PPARa mRNA and protein levels follow a daily rhythm, peaking at the end of the resting phase (ZT8-12), and are induced by stressrelated corticosteroids whose plasma levels vary in parallel [112]. PPAR $\beta / \delta$ exhibits an even more striking cyclic expression pattern with a $24 \mathrm{~h}$ period in several murine tissues including the liver, while cycling of Pparg expression is much less pronounced and not always considered as circadian [113]. In this study, hepatic mRNA expression levels peaked around ZT12 for Ppara and ZT8 for Pparg, thus around or just before the switch from the resting/fasting phase to the active/feeding phase, whereas Ppard peaked around ZT20 i.e. towards the end of the active phase. The circadian expression profile of PPAR $\beta / \delta$ is somewhat surprising, as a major function of this isotype is the induction of FAO that mainly occurs during prolonged fasting. It has to be pointed out though that PPAR expression not necessarily coincides with activity, as ligand availability largely determines the functional output. Interestingly, the same study showed that the gene coding for the PPAR dimerization and transactivation partner Rxra (but not Rxrb and Rxrg) also exhibits a rhythmic expression in liver, peaking around ZT8. It is tempting to speculate that, in addition to the relative abundance of PPAR isotypes in the liver, differences in their circadian expression profiles and of their partners could participate in their distinct functions. However, this type of data has always been obtained from bulk liver extracts, which contain not only hepatocytes but also NPCs, and differences between cell types and subpopulations cannot be excluded. Unfortunately, and due to technical limitations, it is not yet possible to compare the transcriptome and proteome with sufficient coverage from multiple cell types from the same organ, in a circadian manner and within the same experiment.

At the molecular level, PPARs and the circadian clock have a bidirectional relationship, as core clock components and PPARs mutually regulate their expression. Indeed, Ppara gene expression is directly transactivated upon binding of the BMAL1-CLOCK heterodimer to Eboxes located in the Ppara promoter, which results in an increased expression of PPAR target genes regulating lipid metabolism $[114,115]$. The same mechanism also probably applies to 
Pparg [116]. In murine liver, rhythmic interaction of PER2 with PPARa bound to PPAR target gene promoters such as Arntl (BMAL1), Hnf1a and G6pc, results in a cyclical transregulation of crucial metabolic genes [117]. In skeletal muscle, the core clock proteins CRY1\&2 directly interact with PPAR $\beta / \delta$ to act as co-repressors for a subset of its target genes, thereby regulating FAO and exercise capacity [118]. In turn, both PPARa [119] and, at least in the cardiovascular system, PPARY [120] directly regulate BMAL1 expression by binding to PPREs in the Arntl gene promoter, thereby subsequently controlling clock output genes. Of note, PPARy coactivator-1 $\alpha$ (PGC1 $\alpha$ ) also induces the expression of Arntl (BMAL1) and of the core clock transrepressor Nr1d1 (REV-ERBa) [121]. PPARa might also directly regulate the expression of REV-ERBa by binding to the RevDR-2 element in its promoter [122]. In addition, REV-ERB $\alpha$ can compete with PPAR $\alpha$ for binding to PPREs located in promoters of several PPAR target genes such as Ehhadh, controlling peroxisomal FAO [123]. Consequently, treatment of mice with PPARa agonists such as fibrates induced Arnt/ [119] and Nr1d1 [122] expression in liver, potentially modulating clock function. In line with this, chronic treatment of mice with the $\operatorname{PPAR}(\alpha)$ agonist bezafibrate altered circadian behavioral rhythms of feeding and locomotor activity without promoting weight gain [124] and might be used therapeutically to "reset" a deregulated clock, as encountered in an experimental model of hepatic fibrosis [125]. In this study, fibrotic livers from $\mathrm{CCl}_{4}$-treated mice displayed altered circadian expression of the clock genes Arntl, Clock, Per1, Cry1//2 and, interestingly, also displayed a loss of rhythmicity of Ppara and cytochrome P450 oxidoreductase (Por) controlling lipid and bile acid metabolism. In accordance with these findings, Ppara or b/d or $g$ knockout mice display altered circadian behavioral rhythms, metabolism- and clock-related gene expression. Inducible whole-body deletion of Pparg resulted in altered food intake, locomotor activity and cardiovascular parameters (heart rate, MAP) and the rhythmicity of canonical clock genes was impaired in liver [126]. Ppara-null mice also exhibited altered hepatic expression of core clock proteins, with BMAL1 being the most affected [119]. Liver-restricted Pparb/d knockout mice had disrupted diurnal oscillations in de novo lipogenesis and plasma FA levels [33].

Beyond a direct regulation of their expression, PPAR activity, stability and localization can be modulated by posttranslational modifications (PTMs) including phosphorylation, SUMOylation, ubiquitination, acetylation, and O-GlcNAcylation, most of which exhibit circadian or feeding status-dependent variations [127]. Phosphorylation of PPAR a at Ser12/21 by MAPKs and Ser73 by GSK3ß, PPARY at Ser112 by ERKs or JNK and Ser273 by CDK5 are amongst the functionally most important PTMs identified to date. Besides, the energy-sensing and cyclically-active AMP-activated protein kinase (AMPK) [128] can interfere with PPARY activity, via phosphorylation of its coregulators $\mathrm{p} 300$ and of PGC1 $\alpha$, and with PPAR $\alpha$ chromatin recruitment by forming a trimeric pAMPK-GR-PPARa complex to modulate target gene expression [129-132]. In addition, some chemical PPAR ligands, including TZDs, fenofibrate 
and WY14643, increase the expression and/or activity of AMPK, potentially implicating this kinase in synthetic PPAR agonist pharmacological activity [133]. Thus, these interactions create a complex regulatory triad formed of clock proteins, PPARs and AMPK at the crossroads between metabolism and circadian rhythms, whose biological consequences remain to be fully established.

\section{LIVER SEXUAL DIMORPHISM AND PPARs}

In addition to the spatial and temporal regulations, the liver also presents a sexual dimorphism in its architecture, functions and regulations. At the macroscopic level, the male liver is larger than the female liver in rodents [134,135]. At the cellular level, the female rat liver comprises more but smaller and mainly diploid hepatocytes and more KCs when compared to the male liver (for a review see [136]). At the molecular level, this dimorphism is even more pronounced with $13 \%$ of expressed genes presenting a sex-specific profile with a $\log _{2} \mathrm{FC}>1.2$ and up to $72 \%$ of genes with a $\log _{2} \mathrm{FC}>1$ [137]. More specifically, 17 out of the 38 analyzed nuclear receptors display a sex-specific expression, being either male- [e.g. Rarg (Nr1b3), Errb (Nr3b2)) or female-enriched (e.g. Errg (Nr3b3), and Rxrg (Nr2b3)] [138]. Regarding the PPAR isotypes, even though there is a growing literature exploring sex differences in PPAR signaling pathways in rodent models, little information is available in humans, and most studies focused on PPARa. There are striking differences between rodent species. In rats, hepatic Ppara expression is higher in males both at the mRNA and protein levels. This difference could explain why male rats respond stronger to fibrates compared to females [139]. In mice, however, females exhibit higher expression of Ppara [140], a finding that was confirmed recently using RNA-Seq and potentially linked to sex-related differences in gut microbiota [141]. This species-dependent difference was found at both protein and post-translational levels. Indeed, in female liver, PPAR is heavily sumoylated, favoring its interaction with GA Binding Protein Transcription Factor Subunit Alpha (GABPa) on the promoter of Cyp7b1. This complex recruits NCoR and HDACs and Dnmt3 (DNA methyltransferase) allowing a stronger repression of Cyp7b1 expression, protecting the organ from estrogen-induced cholestasis which often occurs during pregnancy [142].

Only one study reported a sex-dependent expression of $P p a r b / d$, with higher expression in female mouse liver around the clock [140]. In addition, analysis of RNAseq data confirmed the sexually dimorphic expression of Pparb/d [141]. Characterization of Ppary in rodent models is still controversial. Indeed, Pparg was initially described as predominantly expressed in female rat liver [138,142]. However, another study reported increased hepatic Pparg expression upon ovariectomy in rats and that activation of ERa blunted this induction [143]. These seemingly opposite observations could be due to a gain of rhythmicity of hepatic Pparg expression in 
females, at least in mice. Indeed, analysis of circadian transcriptomic data of male mouse liver using the CircadiOmics database does not classify Ppary as a circadianly expressed gene [144-146]. However, in contrast to male mice, Pparg expression follows a diurnal cycle peaking at ZT9 in females with a higher expression than in males at this particular timepoint [140]. Sex-related differences in Pparg expression are also due to a sexual dimorphism in growth hormone $(\mathrm{GH})$ secretion and subsequent JAK(2)-STAT(5) signaling. The overall intensity and rhythmicity of GH secretion/signaling are more marked in males, thus maintaining a higher hepatic JAK2/STAT5 activity which represses Pparg expression [141,147].

Finally, assessing the impact of the liver sexual dimorphism on PPAR isotype functions in human liver is a major challenge for the next years in order to develop sex-optimized therapies.

\section{SPECIES-SPECIFIC LIGAND REGULATION OF PPARs}

All three PPAR isotypes are saturated and unsaturated FA sensors and also bind oxidized and nitrated FA derivatives as well as cyclopentenone prostaglandins. Thus, the activities of these nuclear receptors depend on the nutritional state and the inflammation level $[1,5,148]$.

A source of endogenous PPARa ligands has been identified on the basis of defective PPARa target gene activation in fatty acid synthase (FAS)-deficient mice [149]. Further investigation identified 1-palmitoyl-2-oleoyl-sn-glycerol-3-phosphocholine (16:0/18:1-GPC) as a PPARa-specific ligand generated through a FAS-CEPT1 biosynthetic pathway [150]. Similarly, adiponectin receptor 2 (AdipoR2) gene deletion affects the liver PPARa signaling pathway [151]. The intrinsic Zn-dependent ceramidase activity of AdipoR2 [152] generates sphingosine-1-phosphate (S1P) and free fatty acids which activate PPARa [153]. Ectopic expression of the lipogenic gene SREBP1c generates lipophilic molecules able to selectively activate PPARY [154]. The anti-inflammatory mediator 15-deoxy-D12,14-prostaglandin J2 (15d-PGJ2) is generated from arachidonic acid and has been suggested to be a physiological ligand for PPARY [155], although this conclusion has raised some controversy in light of the observed 15d-PGJ2 concentrations in pathophysiological conditions [156]. Multiple other lipophilic molecules generated through diverse biosynthetic pathways have been proposed to activate PPARs [157].

Importantly, ligand binding can be isotype-specific. Both PPAR $\alpha$ and PPAR $\beta / \delta$ are able to bind to saturated and unsaturated FAs even if PPARa has a better affinity for these molecules compared to PPAR $\beta$. PPARy binds preferentially unsaturated FA, with a marked affinity for polyunsaturated vs monounsaturated FAs [158,159]. In addition, several studies described species specificities in ligand binding affinity, especially for PPAR $\alpha$ and PPAR $\beta / \delta$. While rodent and human PPARa equally bind ligands such as unsaturated long chain FA (LCFA) and LCFACoA, other natural and synthetic ligands bind PPARa in a species-dependent manner [160]. Saturated LCFAs like palmitic or stearic acids weakly bind mouse PPARa compared to its 
human ortholog [161]. It is worth noting that this species specificity also affects the binding affinity of synthetic ligands. Indeed, fenofibrate, bezafibrate and $\mathrm{Wy}-14,643$ activate mouse PPARa more potently than human PPARa [7], a feature to be considered when interpreting the results of in vitro and in vivo pharmacological experiments.

To the best of our knowledge, the species specificity of natural PPAR $\beta / \delta$ agonists has not been studied yet $[1,148,162]$ and studies focused essentially on endocrine disruptors or potential therapeutic drugs. Treatment with the synthetic PPAR $\beta / \delta$ agonist NNC61-5920 improved insulin sensitivity in mice fed a high fat diet, but this beneficial effect was not observed in a similar rat model [163]. Another PPARß/ठ agonist, GW501516, improved metabolic parameters such as insulin sensitivity, TG, LDL-cholesterol, Apoa1 and HDLcholesterol blood levels in type 2 diabetic rodents and obese primates as well as in sedentary human volunteers [164], unraveling the biological effects of PPAR $\beta / \delta$ activation in man. However, clinical development of this drug was halted due to cancer development in mice [165].

Similar to PPARß/ס, little is known on the species-specific differences of PPARy orthologue activation by natural ligands such as unsaturated FAs (e.g., arachidonic acid) and their derivatives (hydroxy-eicosatetraenoic acid, hydroxy-octadecadienoic acids and 15d-PGJ2) [1]. However, mouse and human PPARY share 99\% amino acid identity in the ligand binding domain, suggesting that mPPARy and hPPARy have similar ligand binding properties. In contrast, mouse and human PPARa and PPAR $/ \delta$ harbor $8 \%$ and $5 \%$ amino acid divergence respectively, which may potentially impact on ligand-receptor interactions. This feature could explain the species-specific differences in affinity of the $\alpha$ and $\beta / \delta$ isotypes for their natural or synthetic ligands. Of note, as preclinical drug validation is based on the use of animal models (mostly rodents), the comparison between mouse and human ligand affinity/specificity is a key point in the drug design pipeline.

\section{NATURAL PPAR MUTANTS}

The human NR1C1 and NR1C2 genes barely present any nucleotide polymorphisms. Indeed, to our knowledge there is no PPARD and only one PPARA mutation affecting their protein coding sequences $[166,167]$. The human NR1C3 gene, in contrast, harbors several SNPs (for review see [168]). However, as PPARY is mainly expressed in adipose tissue, these mutations may only be of minor relevance for hepatic physiology, although a formal investigation would be informative.

\section{CONCLUSION AND PERSPECTIVES.}


The liver cellular architecture dictates a precise division of labor which evolves circadianly and in response to gradients of nutrients and oxygen. In addition, noticeable differences are observed between male and female livers and as a function of species. Several transcription factors and nuclear receptors play key roles in determining the functional complexity and adaptability of the liver, in which PPARs play critical roles. Here we reviewed the different roles of PPAR isotypes in liver physiology, from their firstly-discovered functions as transcriptional activators to most recent data, highlighting still open questions and new challenges to guide future research in the field.

Since the seminal discovery of the first PPAR (alpha) nuclear receptor by Issemann and Green in 1990 [161], our knowledge about this subclass of transcriptional modulators has drastically increased. We now have a good understanding of the general mechanisms of action of the three PPAR isotypes in different organs. Most of the initial studies on PPARs focused on their metabolic functions in liver, so it is not surprising that PPARs were first assimilated as major metabolic regulators. Combined with their anti-inflammatory actions, these properties spurred intense investigations to target PPARs to manage liver pathologies (Table 1). In fact, pharmacological agonism of PPAR isotypes has been extensively assessed in clinical trials over the last decades, mainly to correct metabolic dysregulations such as T2D, dyslipidemia and NASH. Although improving glycemia and cardiovascular risk factors (plasma triglycerides and cholesterol), targeting NAFLD/NASH through PPAR agonists has yielded mitigated results. Several PPAR agonists are now being developed to manage other hepatic pathologies including (PBC), with promising preliminary results (Table 1).

Whereas studies on whole liver have undoubtedly contributed to our knowledge on PPAR functions [6], an in-depth and cell type-specific approach is now required to further discriminate PPAR activities. Such an approach has already confirmed some, and unraveled new principles of liver physiology [53,54], but has to be extended to address specific questions in the field of PPAR biology. PPARs are indeed differentially expressed in liver cells, where they exert specific functions depending on agonist availability and very probably on the epigenomic and transcriptional machinery architecture. PPAR expression and/or activity are also likely to be affected by liver zonation, in addition to being regulated by the circadian rhythm, the nutritional status and in a sex-specific manner [7,8]. These emerging concepts will require further investigations using cutting-edge technologies to decipher the exact mechanism(s) of action of PPARs in physiological conditions. Data suggesting that Ppara and Pparg are expressed in a zonated manner must be considered with caution as they are collected at a single time point which is hardly connectable to a physiological state reflecting a precise nutritional and circadian status. Although expression does not equal activity, these technical limitations could explain, for example, why the Ppara gene is seemingly more expressed in pericentral areas, while $\beta$ oxidation mainly takes place in periportal hepatocytes. This is especially important as, in 
general, animal studies report the nutritional status at the time of sacrifice, but give no information about the time of the day when this was carried out (ZT). Chronobiology reveals that the expression of PPARs is not constant over time and that Ppara and Ppard expressions are anti-phasic. For example, PPAR $/ \delta$ is usually described as weakly expressed in the liver, but most studies are typically carried out during the day when its circadian expression is at its nadir. Conversely to PPAR $\alpha$ and PPAR $/ \delta$, PPARy presents a sex-specific circadian rhythmicity, at least in mouse liver. Thus, it could be really useful for future research and therapies to take into account these time- and sex-related aspects.

Over the last years, new exciting data added to our knowledge on hepatic PPARs and the many regulatory mechanisms acting in concert to regulate their activities. Nevertheless, further studies are required to complete our understanding of the complex roles of PPARs in hepatic physiology and pave the way for more targeted and better optimized therapeutic approaches in the fight against increasingly common liver pathologies and metabolic dysregulations. 


\section{ACKNOWLEDGMENTS}

MJ is supported by a Bourse d'excellence WBI.World (ref. SOR/2019/441207) of WallonieBruxelles International (WBI). B.S. is supported by the European Research Council (ERC Grant Immunobile, contract 694717). This work was financed by grants from the Fondation pour la Recherche Médicale (Equipe labellisée, DEQ20150331724), CPER CTRL 18 FEDER Chol-O-Rev, "European Genomic Institute for Diabetes" (E.G.I.D., ANR10-LABX-46) and by the European Union under the European Regional Development Fund (ERDF), by the Hauts de France Regional Council, the Métropole Européenne de Lille (contract n²017_ESR_14), and the French State (contract $\left.n^{\circ} 2018-R 3-C T R L-P h a s e 2\right)$.

Conflicts of Interest: BS is a consultant of Genfit SA. The other authors have no potential conflicts of interest to disclose. 


\section{BIBLIOGRAPHY}

[1] B. Gross, M. Pawlak, P. Lefebvre, B. Staels, PPARs in obesity-induced T2DM, dyslipidaemia and NAFLD, Nat. Rev. Endocrinol. 13 (2017) 36-49. https://doi.org/10.1038/nrendo.2016.135.

[2] Y. Wang, T. Nakajima, F.J. Gonzalez, N. Tanaka, PPARs as Metabolic Regulators in the Liver: Lessons from Liver-Specific PPAR-Null Mice, Int. J. Mol. Sci. 21 (2020) 2061. https://doi.org/10.3390/ijms21062061.

[3] Z. Kang, R. Fan, PPARa and NCOR/SMRT corepressor network in liver metabolic regulation, FASEB J. Off. Publ. Fed. Am. Soc. Exp. Biol. (2020). https://doi.org/10.1096/fj.202000055RR.

[4] N. Viswakarma, Y. Jia, L. Bai, A. Vluggens, J. Borensztajn, J. Xu, J.K. Reddy, Coactivators in PPAR-Regulated Gene Expression, PPAR Res. 2010 (2010). https://doi.org/10.1155/2010/250126.

[5] N. Venteclef, T. Jakobsson, K.R. Steffensen, E. Treuter, Metabolic nuclear receptor signaling and the inflammatory acute phase response, Trends Endocrinol. Metab. TEM. 22 (2011) 333-343. https://doi.org/10.1016/j.tem.2011.04.004.

[6] M. Pawlak, P. Lefebvre, B. Staels, Molecular mechanism of PPARa action and its impact on lipid metabolism, inflammation and fibrosis in non-alcoholic fatty liver disease, J. Hepatol. 62 (2015) 720-733. https://doi.org/10.1016/j.jhep.2014.10.039.

[7] V. Dubois, J. Eeckhoute, P. Lefebvre, B. Staels, Distinct but complementary contributions of PPAR isotypes to energy homeostasis, J. Clin. Invest. 127 (2017) 1202-1214. https://doi.org/10.1172/JCl88894.

[8] J. Vandel, J. Dubois-Chevalier, C. Gheeraert, B. Derudas, V. Raverdy, D. Thuillier, L. Van Gaal, S. Francque, F. Pattou, B. Staels, J. Eeckhoute, P. Lefebvre, Hepatic molecular signatures highlight the sexual dimorphism of Non-Alcoholic SteatoHepatitis (NASH), Hepatol. Baltim. Md. (2020). https://doi.org/10.1002/hep.31312.

[9] N.S. Choudhary, N. Kumar, A. Duseja, Peroxisome Proliferator-Activated Receptors and Their Agonists in Nonalcoholic Fatty Liver Disease, J. Clin. Exp. Hepatol. 9 (2019) 731739. https://doi.org/10.1016/j.jceh.2019.06.004.

[10]Y.K. Lee, J.E. Park, M. Lee, J.P. Hardwick, Hepatic lipid homeostasis by peroxisome proliferator-activated receptor gamma 2, Liver Res. 2 (2018) 209-215. https://doi.org/10.1016/j.livres.2018.12.001.

[11]C. Janani, B.D. Ranjitha Kumari, PPAR gamma gene--a review, Diabetes Metab. Syndr. 9 (2015) 46-50. https://doi.org/10.1016/j.dsx.2014.09.015.

[12]J. Zhou, K.M. Wilson, J.D. Medh, Genetic analysis of four novel peroxisome proliferator activated receptor-gamma splice variants in monkey macrophages, Biochem. Biophys. Res. Commun. 293 (2002) 274-283. https://doi.org/10.1016/S0006-291X(02)00138-9.

[13]L.A. Bojic, D.E. Telford, M.D. Fullerton, R.J. Ford, B.G. Sutherland, J.Y. Edwards, C.G. Sawyez, R. Gros, B.E. Kemp, G.R. Steinberg, M.W. Huff, PPARס activation attenuates hepatic steatosis in Ldlr-/- mice by enhanced fat oxidation, reduced lipogenesis, and improved insulin sensitivity, J. Lipid Res. 55 (2014) 1254-1266. https://doi.org/10.1194/jlr.M046037.

[14]A. Montagner, A. Polizzi, E. Fouché, S. Ducheix, Y. Lippi, F. Lasserre, V. Barquissau, M. Régnier, C. Lukowicz, F. Benhamed, A. Iroz, J. Bertrand-Michel, T. Al Saati, P. Cano, L. Mselli-Lakhal, G. Mithieux, F. Rajas, S. Lagarrigue, T. Pineau, N. Loiseau, C. Postic, D. Langin, W. Wahli, H. Guillou, Liver PPARa is crucial for whole-body fatty acid homeostasis and is protective against NAFLD, Gut. 65 (2016) 1202-1214. https://doi.org/10.1136/gutjnl-2015-310798.

[15]A. Iroz, A. Montagner, F. Benhamed, F. Levavasseur, A. Polizzi, E. Anthony, M. Régnier, E. Fouché, C. Lukowicz, M. Cauzac, E. Tournier, M. Do-Cruzeiro, M. Daujat-Chavanieu, S. Gerbal-Chalouin, V. Fauveau, S. Marmier, A.-F. Burnol, S. Guilmeau, Y. Lippi, J. Girard, W. Wahli, R. Dentin, H. Guillou, C. Postic, A Specific ChREBP and PPARa Cross-Talk Is Required for the Glucose-Mediated FGF21 Response, Cell Rep. 21 (2017) 403-416. https://doi.org/10.1016/j.celrep.2017.09.065. 
[16]K.H. Kim, D.D. Moore, Regulation of Liver Energy Balance by the Nuclear Receptors Farnesoid X Receptor and Peroxisome Proliferator Activated Receptor $\alpha$, Dig. Dis. 35 (2017) 203-209. https://doi.org/10.1159/000450912.

[17]J.M. Lee, Transcriptional coordination of hepatic autophagy by nutrient-sensing nuclear receptor PPARa and FXR, Ann. Pediatr. Endocrinol. Metab. 21 (2016) 193-198. https://doi.org/10.6065/apem.2016.21.4.193.

[18]F. Damiano, G.V. Gnoni, L. Siculella, Citrate carrier promoter is target of peroxisome proliferator-activated receptor alpha and gamma in hepatocytes and adipocytes, Int. J. Biochem. Cell Biol. 44 (2012) 659-668. https://doi.org/10.1016/j.biocel.2012.01.003.

[19]B.L. Knight, A. Hebbachi, D. Hauton, A.-M. Brown, D. Wiggins, D.D. Patel, G.F. Gibbons, A role for PPARalpha in the control of SREBP activity and lipid synthesis in the liver, Biochem. J. 389 (2005) 413-421. https://doi.org/10.1042/BJ20041896.

[20]C.N. Brocker, D.P. Patel, T.J. Velenosi, D. Kim, T. Yan, J. Yue, G. Li, K.W. Krausz, F.J. Gonzalez, Extrahepatic PPARa modulates fatty acid oxidation and attenuates fastinginduced hepatosteatosis in mice, J. Lipid Res. 59 (2018) 2140-2152. https://doi.org/10.1194/jlr.M088419.

[21]E. Morán-Salvador, E. Titos, B. Rius, A. González-Périz, V. García-Alonso, C. LópezVicario, R. Miquel, Y. Barak, V. Arroyo, J. Clària, Cell-specific PPARy deficiency establishes anti-inflammatory and anti-fibrogenic properties for this nuclear receptor in non-parenchymal liver cells, J. Hepatol. 59 (2013) 1045-1053. https://doi.org/10.1016/j.jhep.2013.06.023.

[22]S. Yu, K. Matsusue, P. Kashireddy, W.-Q. Cao, V. Yeldandi, A.V. Yeldandi, M.S. Rao, F.J. Gonzalez, J.K. Reddy, Adipocyte-specific gene expression and adipogenic steatosis in the mouse liver due to peroxisome proliferator-activated receptor gamma1 (PPARgamma1) overexpression, J. Biol. Chem. 278 (2003) 498-505. https://doi.org/10.1074/jbc.M210062200.

[23]K. Uno, H. Katagiri, T. Yamada, Y. Ishigaki, T. Ogihara, J. Imai, Y. Hasegawa, J. Gao, K. Kaneko, H. Iwasaki, H. Ishihara, H. Sasano, K. Inukai, H. Mizuguchi, T. Asano, M. Shiota, M. Nakazato, Y. Oka, Neuronal pathway from the liver modulates energy expenditure and systemic insulin sensitivity, Science. 312 (2006) 1656-1659. https://doi.org/10.1126/science.1126010.

[24]E. Morán-Salvador, M. López-Parra, V. García-Alonso, E. Titos, M. Martínez-Clemente, A. González-Périz, C. López-Vicario, Y. Barak, V. Arroyo, J. Clària, Role for PPARY in obesity-induced hepatic steatosis as determined by hepatocyte- and macrophage-specific conditional knockouts, FASEB J. Off. Publ. Fed. Am. Soc. Exp. Biol. 25 (2011) 2538-2550. https://doi.org/10.1096/fj.10-173716.

[25]O. Gavrilova, M. Haluzik, K. Matsusue, J.J. Cutson, L. Johnson, K.R. Dietz, C.J. Nicol, C. Vinson, F.J. Gonzalez, M.L. Reitman, Liver peroxisome proliferator-activated receptor gamma contributes to hepatic steatosis, triglyceride clearance, and regulation of body fat mass, J. Biol. Chem. 278 (2003) 34268-34276. https://doi.org/10.1074/jbc.M300043200.

[26]N. Maeda, M. Takahashi, T. Funahashi, S. Kihara, H. Nishizawa, K. Kishida, H. Nagaretani, M. Matsuda, R. Komuro, N. Ouchi, H. Kuriyama, K. Hotta, T. Nakamura, I. Shimomura, Y. Matsuzawa, PPARgamma ligands increase expression and plasma concentrations of adiponectin, an adipose-derived protein, Diabetes. 50 (2001) 20942099. https://doi.org/10.2337/diabetes.50.9.2094.

[27]P. Handa, B.D. Maliken, J.E. Nelson, V. Morgan-Stevenson, D.J. Messner, B.K. Dhillon, H.M. Klintworth, M. Beauchamp, M.M. Yeh, C.T. Elfers, C.L. Roth, K.V. Kowdley, Reduced adiponectin signaling due to weight gain results in nonalcoholic steatohepatitis through impaired mitochondrial biogenesis, Hepatol. Baltim. Md. 60 (2014) 133-145. https://doi.org/10.1002/hep.26946.

[28]E. Barroso, R. Rodríguez-Calvo, L. Serrano-Marco, A.M. Astudillo, J. Balsinde, X. Palomer, M. Vázquez-Carrera, The PPARß/ठ activator GW501516 prevents the downregulation of AMPK caused by a high-fat diet in liver and amplifies the PGC-1a-Lipin 1PPARa pathway leading to increased fatty acid oxidation, Endocrinology. 152 (2011) 1848-1859. https://doi.org/10.1210/en.2010-1468. 
[29]P. Thulin, B. Glinghammar, J. Skogsberg, K. Lundell, E. Ehrenborg, PPARס increases expression of the human apolipoprotein A-II gene in human liver cells, Int. J. Mol. Med. (2008). https://doi.org/10.3892/ijmm.21.6.819.

[30]K. Chehaibi, L. Cedó, J. Metso, X. Palomer, D. Santos, H. Quesada, M. Naceur Slimane, W. Wahli, J. Julve, M. Vázquez-Carrera, M. Jauhiainen, F. Blanco-Vaca, J.C. Escolà-Gil, PPAR- $\beta / \delta$ activation promotes phospholipid transfer protein expression, Biochem. Pharmacol. 94 (2015) 101-108. https://doi.org/10.1016/j.bcp.2015.01.016.

[31]C.-H. Lee, P. Olson, A. Hevener, I. Mehl, L.-W. Chong, J.M. Olefsky, F.J. Gonzalez, J. Ham, H. Kang, J.M. Peters, R.M. Evans, PPARdelta regulates glucose metabolism and insulin sensitivity, Proc. Natl. Acad. Sci. U. S. A. 103 (2006) 3444-3449. https://doi.org/10.1073/pnas.0511253103.

[32]S. Liu, B. Hatano, M. Zhao, C.-C. Yen, K. Kang, S.M. Reilly, M.R. Gangl, C. Gorgun, J.A. Balschi, J.M. Ntambi, C.-H. Lee, Role of peroxisome proliferator-activated receptor \{delta\}/\{beta\} in hepatic metabolic regulation, J. Biol. Chem. 286 (2011) 1237-1247. https://doi.org/10.1074/jbc.M110.138115.

[33]S. Liu, J.D. Brown, K.J. Stanya, E. Homan, M. Leidl, K. Inouye, P. Bhargava, M.R. Gangl, L. Dai, B. Hatano, G.S. Hotamisligil, A. Saghatelian, J. Plutzky, C.-H. Lee, A diurnal serum lipid integrates hepatic lipogenesis and peripheral fatty acid use, Nature. 502 (2013) 550554. https://doi.org/10.1038/nature12710.

[34]W. Wahli, L. Michalik, PPARs at the crossroads of lipid signaling and inflammation, Trends Endocrinol. Metab. TEM. 23 (2012) 351-363. https://doi.org/10.1016/j.tem.2012.05.001.

[35]A. Christofides, E. Konstantinidou, C. Jani, V.A. Boussiotis, The role of Peroxisome Proliferator-Activated Receptors (PPAR) in immune responses, Metabolism. (2020) 154338. https://doi.org/10.1016/j.metabol.2020.154338.

[36]R. Stienstra, F. Saudale, C. Duval, S. Keshtkar, J.E.M. Groener, N. van Rooijen, B. Staels, S. Kersten, M. Müller, Kupffer cells promote hepatic steatosis via interleukin-1 $\beta$-dependent suppression of peroxisome proliferator-activated receptor $\alpha$ activity, Hepatology. 51 (2010) 511-522. https://doi.org/10.1002/hep.23337.

[37]M. Krishna, Microscopic anatomy of the liver, Clin. Liver Dis. 2 (2013) S4-S7. https://doi.org/10.1002/cld.147.

[38]C. Berasain, M.A. Avila, Regulation of hepatocyte identity and quiescence, Cell. Mol. Life Sci. 72 (2015) 3831-3851. https://doi.org/10.1007/s00018-015-1970-7.

[39]S. Liu, L.M. Luttrell, R.T. Premont, D.C. Rockey, $\beta$-Arrestin2 is a critical component of the GPCR-eNOS signalosome, Proc. Natl. Acad. Sci. 117 (2020) 11483-11492. https://doi.org/10.1073/pnas.1922608117.

[40]J. Poisson, S. Lemoinne, C. Boulanger, F. Durand, R. Moreau, D. Valla, P.-E. Rautou, Liver sinusoidal endothelial cells: Physiology and role in liver diseases, J. Hepatol. 66 (2017) 212-227. https://doi.org/10.1016/j.jhep.2016.07.009.

[41]E. Lafoz, M. Ruart, A. Anton, A. Oncins, V. Hernández-Gea, The Endothelium as a Driver of Liver Fibrosis and Regeneration, Cells. $9 \quad$ (2020) 929. https://doi.org/10.3390/cells9040929.

[42]L.J. Dixon, M. Barnes, H. Tang, M.T. Pritchard, L.E. Nagy, Kupffer Cells in the Liver, in: R. Terjung (Ed.), Compr. Physiol., John Wiley \& Sons, Inc., Hoboken, NJ, USA, 2013: p. c120026. http://doi.wiley.com/10.1002/cphy.c120026 (accessed March 23, 2020).

[43]T. Tsuchida, S.L. Friedman, Mechanisms of hepatic stellate cell activation, Nat. Rev. Gastroenterol. Hepatol. 14 (2017) 397-411. https://doi.org/10.1038/nrgastro.2017.38.

[44]M. Bobowski-Gerard, F. Zummo, B. Staels, P. Lefebvre, J. Eeckhoute, Retinoids Issued from Hepatic Stellate Cell Lipid Droplet Loss as Potential Signaling Molecules Orchestrating a Multicellular Liver Injury Response, Cells. 7 (2018) 137. https://doi.org/10.3390/cells7090137.

[45]A. Raven, W.-Y. Lu, T.Y. Man, S. Ferreira-Gonzalez, E. O'Duibhir, B.J. Dwyer, J.P. Thomson, R.R. Meehan, R. Bogorad, V. Koteliansky, Y. Kotelevtsev, C. ffrench-Constant, L. Boulter, S.J. Forbes, Cholangiocytes act as facultative liver stem cells during impaired $\begin{array}{lllll}\text { hepatocyte } & \text { regeneration, } & \text { Nature. } & 547 & \text { (2017) }\end{array}$ https://doi.org/10.1038/nature23015. 
[46]T. Kisseleva, The origin of fibrogenic myofibroblasts in fibrotic liver, Hepatology. 65 (2017) 1039-1043. https://doi.org/10.1002/hep.28948.

[47]I. Lua, K. Asahina, The Role of Mesothelial Cells in Liver Development, Injury, and Regeneration, Gut Liver. 10 (2016) 166. https://doi.org/10.5009/gnl15226.

[48]Y. Koyama, D.A. Brenner, Liver inflammation and fibrosis, J. Clin. Invest. 127 (2017) 5564. https://doi.org/10.1172/JCl88881.

[49]F. Heymann, F. Tacke, Immunology in the liver — from homeostasis to disease, Nat. Rev. Gastroenterol. Hepatol. 13 (2016) 88-110. https://doi.org/10.1038/nrgastro.2015.200.

[50]Z. Li, J.K. Kruijt, R.J. van der Sluis, T.J.C.V. Berkel, M. Hoekstra, Nuclear receptor atlas of female mouse liver parenchymal, endothelial, and Kupffer cells, Physiol. Genomics. 45 (2013) 268-275. https://doi.org/10.1152/physiolgenomics.00151.2012.

[51]E. Gonzalez-Sanchez, D. Firrincieli, C. Housset, N. Chignard, Expression patterns of nuclear receptors in parenchymal and non-parenchymal mouse liver cells and their modulation in cholestasis, Biochim. Biophys. Acta BBA - Mol. Basis Dis. 1863 (2017) 1699-1708. https://doi.org/10.1016/j.bbadis.2017.04.004.

[52]K. Hellemans, K. Rombouts, E. Quartier, A.S. Dittié, A. Knorr, L. Michalik, V. Rogiers, F. Schuit, W. Wahli, A. Geerts, PPAR $\beta$ regulates vitamin A metabolism-related gene expression in hepatic stellate cells undergoing activation, J. Lipid Res. 44 (2003) 280-295. https://doi.org/10.1194/jlr.M200376-JLR200.

[53]P. Ramachandran, R. Dobie, J.R. Wilson-Kanamori, E.F. Dora, B.E.P. Henderson, N.T. Luu, J.R. Portman, K.P. Matchett, M. Brice, J.A. Marwick, R.S. Taylor, M. Efremova, R. Vento-Tormo, N.O. Carragher, T.J. Kendall, J.A. Fallowfield, E.M. Harrison, D.J. Mole, S.J. Wigmore, P.N. Newsome, C.J. Weston, J.P. Iredale, F. Tacke, J.W. Pollard, C.P. Ponting, J.C. Marioni, S.A. Teichmann, N.C. Henderson, Resolving the fibrotic niche of human liver cirrhosis at single-cell level, Nature. 575 (2019) 512-518. https://doi.org/10.1038/s41586019-1631-3.

[54]X. Han, Z. Zhou, L. Fei, H. Sun, R. Wang, Y. Chen, H. Chen, J. Wang, H. Tang, W. Ge, Y. Zhou, F. Ye, M. Jiang, J. Wu, Y. Xiao, X. Jia, T. Zhang, X. Ma, Q. Zhang, X. Bai, S. Lai, C. Yu, L. Zhu, R. Lin, Y. Gao, M. Wang, Y. Wu, J. Zhang, R. Zhan, S. Zhu, H. Hu, C. Wang, M. Chen, H. Huang, T. Liang, J. Chen, W. Wang, D. Zhang, G. Guo, Construction of a human cell landscape at single-cell level, Nature. 581 (2020) 303-309. https://doi.org/10.1038/s41586-020-2157-4.

[55]C.N. Brocker, J. Yue, D. Kim, A. Qu, J.A. Bonzo, F.J. Gonzalez, Hepatocyte-specific PPARA expression exclusively promotes agonist-induced cell proliferation without influence from nonparenchymal cells, Am. J. Physiol. Gastrointest. Liver Physiol. 312 (2017) G283-G299. https://doi.org/10.1152/ajpgi.00205.2016.

[56]W. Luo, Q. Xu, Q. Wang, H. Wu, J. Hua, Effect of modulation of PPAR-y activity on Kupffer cells M1/M2 polarization in the development of non-alcoholic fatty liver disease, Sci. Rep. 7 (2017) 44612. https://doi.org/10.1038/srep44612.

[57]J.I. Odegaard, R.R. Ricardo-Gonzalez, A. Red Eagle, D. Vats, C.R. Morel, M.H. Goforth, V. Subramanian, L. Mukundan, A.W. Ferrante, A. Chawla, Alternative M2 activation of Kupffer cells by PPARdelta ameliorates obesity-induced insulin resistance, Cell Metab. 7 (2008) 496-507. https://doi.org/10.1016/j.cmet.2008.04.003.

[58]K. Iwaisako, M. Haimerl, Y.-H. Paik, K. Taura, Y. Kodama, C. Sirlin, E. Yu, R.T. Yu, M. Downes, R.M. Evans, D.A. Brenner, B. Schnabl, Protection from liver fibrosis by a peroxisome proliferator-activated receptor $\delta$ agonist, Proc. Natl. Acad. Sci. U. S. A. 109 (2012) E1369-1376. https://doi.org/10.1073/pnas.1202464109.

[59]T. Miyahara, L. Schrum, R. Rippe, S. Xiong, H.F. Yee, K. Motomura, F.A. Anania, T.M. Willson, H. Tsukamoto, Peroxisome proliferator-activated receptors and hepatic stellate cell activation, J. Biol. Chem. 275 (2000) 35715-35722. https://doi.org/10.1074/jbc.M006577200.

[60]F. Marra, E. Efsen, R.G. Romanelli, A. Caligiuri, S. Pastacaldi, G. Batignani, A. Bonacchi, R. Caporale, G. Laffi, M. Pinzani, P. Gentilini, Ligands of peroxisome proliferator-activated receptor gamma modulate profibrogenic and proinflammatory actions in hepatic stellate cells, Gastroenterology. 119 (2000) 466-478. https://doi.org/10.1053/gast.2000.9365. 
[61]A. Galli, D.W. Crabb, E. Ceni, R. Salzano, T. Mello, G. Svegliati-Baroni, F. Ridolfi, L. Trozzi, C. Surrenti, A. Casini, Antidiabetic thiazolidinediones inhibit collagen synthesis and hepatic stellate cell activation in vivo and in vitro, Gastroenterology. 122 (2002) 1924-1940. https://doi.org/10.1053/gast.2002.33666.

[62]F. Zhang, D. Kong, Y. Lu, S. Zheng, Peroxisome proliferator-activated receptor-Y as a therapeutic target for hepatic fibrosis: from bench to bedside, Cell. Mol. Life Sci. CMLS. 70 (2013) 259-276. https://doi.org/10.1007/s00018-012-1046-x.

[63]N. Aizarani, A. Saviano, Sagar, L. Mailly, S. Durand, J.S. Herman, P. Pessaux, T.F. Baumert, D. Grün, A human liver cell atlas reveals heterogeneity and epithelial progenitors, Nature. 572 (2019) 199-204. https://doi.org/10.1038/s41586-019-1373-2.

[64]B. Lefebvre, Y. Benomar, A. Guédin, A. Langlois, N. Hennuyer, J. Dumont, E. Bouchaert, C. Dacquet, L. Pénicaud, L. Casteilla, F. Pattou, A. Ktorza, B. Staels, P. Lefebvre, Proteasomal degradation of retinoid $X$ receptor a reprograms transcriptional activity of PPARY in obese mice and humans, J. Clin. Invest. 120 (2010) 1454-1468. https://doi.org/10.1172/JCl38606.

[65]S.C. van den Brink, F. Sage, Á. Vértesy, B. Spanjaard, J. Peterson-Maduro, C.S. Baron, C. Robin, A. van Oudenaarden, Single-cell sequencing reveals dissociation-induced gene expression in tissue subpopulations, Nat. Methods. 14 (2017) 935-936. https://doi.org/10.1038/nmeth.4437.

[66]B. Vollmar, M.D. Menger, The Hepatic Microcirculation: Mechanistic Contributions and Therapeutic Targets in Liver Injury and Repair, Physiol. Rev. 89 (2009) 1269-1339. https://doi.org/10.1152/physrev.00027.2008.

[67]F. Atger, C. Gobet, J. Marquis, E. Martin, J. Wang, B. Weger, G. Lefebvre, P. Descombes, F. Naef, F. Gachon, Circadian and feeding rhythms differentially affect rhythmic mRNA transcription and translation in mouse liver, Proc. Natl. Acad. Sci. U. S. A. 112 (2015) E6579-6588. https://doi.org/10.1073/pnas.1515308112.

[68]B.J. Stewart, J.R. Ferdinand, M.D. Young, T.J. Mitchell, K.W. Loudon, A.M. Riding, N. Richoz, G.L. Frazer, J.U.L. Staniforth, F.A. Vieira Braga, R.A. Botting, D.-M. Popescu, R. Vento-Tormo, E. Stephenson, A. Cagan, S.J. Farndon, K. Polanski, M. Efremova, K. Green, M. Del Castillo Velasco-Herrera, C. Guzzo, G. Collord, L. Mamanova, T. Aho, J.N. Armitage, A.C.P. Riddick, I. Mushtaq, S. Farrell, D. Rampling, J. Nicholson, A. Filby, J. Burge, S. Lisgo, S. Lindsay, M. Bajenoff, A.Y. Warren, G.D. Stewart, N. Sebire, N. Coleman, M. Haniffa, S.A. Teichmann, S. Behjati, M.R. Clatworthy, Spatiotemporal immune zonation of the human kidney, Science. 365 (2019) 1461-1466. https://doi.org/10.1126/science.aat5031.

[69]A.E. Moor, Y. Harnik, S. Ben-Moshe, E.E. Massasa, M. Rozenberg, R. Eilam, K. Bahar Halpern, S. Itzkovitz, Spatial Reconstruction of Single Enterocytes Uncovers Broad Zonation along the Intestinal Villus Axis, Cell. 175 (2018) 1156-1167.e15. https://doi.org/10.1016/j.cell.2018.08.063.

[70]M. Vanlandewijck, L. He, M.A. Mäe, J. Andrae, K. Ando, F. Del Gaudio, K. Nahar, T. Lebouvier, B. Laviña, L. Gouveia, Y. Sun, E. Raschperger, M. Räsänen, Y. Zarb, N. Mochizuki, A. Keller, U. Lendahl, C. Betsholtz, A molecular atlas of cell types and zonation in the brain vasculature, Nature. 554 (2018) 475-480. https://doi.org/10.1038/nature25739.

[71]J. Yang, L.E. Mowry, K.N. Nejak-Bowen, H. Okabe, C.R. Diegel, R.A. Lang, B.O. Williams, S.P. Monga, $\beta$-catenin signaling in murine liver zonation and regeneration: a Wnt-Wnt situation!, Hepatol. Baltim. Md. 60 (2014) 964-976. https://doi.org/10.1002/hep.27082.

[72] K.B. Halpern, R. Shenhav, O. Matcovitch-Natan, B. Toth, D. Lemze, M. Golan, E.E. Massasa, S. Baydatch, S. Landen, A.E. Moor, A. Brandis, A. Giladi, A.S. Avihail, E. David, I. Amit, S. Itzkovitz, Single-cell spatial reconstruction reveals global division of labour in the mammalian liver, Nature. 542 (2017) 352-356. https://doi.org/10.1038/nature21065.

[73]T. Kietzmann, Metabolic zonation of the liver: The oxygen gradient revisited, Redox Biol. 11 (2017) 622-630. https://doi.org/10.1016/j.redox.2017.01.012.

[74]K. Jungermann, T. Keitzmann, Zonation of Parenchymal and Nonparenchymal Metabolism in Liver, (1996) 25. 
[75]S. Ben-Moshe, S. Itzkovitz, Spatial heterogeneity in the mammalian liver, Nat. Rev. Gastroenterol. Hepatol. 16 (2019) 395-410. https://doi.org/10.1038/s41575-019-0134-x.

[76]F. Braet, E. Wisse, Structural and functional aspects of liver sinusoidal endothelial cell fenestrae: a review, Comp. Hepatol. (2002) 17.

[77]R. Dobie, J.R. Wilson-Kanamori, B.E.P. Henderson, J.R. Smith, K.P. Matchett, J.R. Portman, K. Wallenborg, S. Picelli, A. Zagorska, S.V. Pendem, T.E. Hudson, M.M. Wu, G.R. Budas, D.G. Breckenridge, E.M. Harrison, D.J. Mole, S.J. Wigmore, P. Ramachandran, C.P. Ponting, S.A. Teichmann, J.C. Marioni, N.C. Henderson, Single-Cell Transcriptomics Uncovers Zonation of Function in the Mesenchyme during Liver Fibrosis, Cell Rep. 29 (2019) 1832-1847.e8. https://doi.org/10.1016/j.celrep.2019.10.024.

[78]S.A. MacParland, J.C. Liu, X.-Z. Ma, B.T. Innes, A.M. Bartczak, B.K. Gage, J. Manuel, N. Khuu, J. Echeverri, I. Linares, R. Gupta, M.L. Cheng, L.Y. Liu, D. Camat, S.W. Chung, R.K. Seliga, Z. Shao, E. Lee, S. Ogawa, M. Ogawa, M.D. Wilson, J.E. Fish, M. Selzner, A. Ghanekar, D. Grant, P. Greig, G. Sapisochin, N. Selzner, N. Winegarden, O. Adeyi, G. Keller, G.D. Bader, I.D. McGilvray, Single cell RNA sequencing of human liver reveals distinct intrahepatic macrophage populations, Nat. Commun. 9 (2018) 4383. https://doi.org/10.1038/s41467-018-06318-7.

[79]C. Blériot, F. Ginhoux, Understanding the Heterogeneity of Resident Liver Macrophages, Front. Immunol. 10 (2019) 2694. https://doi.org/10.3389/fimmu.2019.02694.

[80]N. Berndt, E. Kolbe, R. Gajowski, J. Eckstein, F. Ott, D. Meierhofer, H.G. Holzhütter, M. Matz-Soja, Functional consequences of metabolic zonation in murine livers: New insights for an old story, Hepatology. (2020) hep.31274. https://doi.org/10.1002/hep.31274.

[81]S. Ghafoory, K. Breitkopf-Heinlein, Q. Li, C. Scholl, S. Dooley, S. Wölfl, Zonation of Nitrogen and Glucose Metabolism Gene Expression upon Acute Liver Damage in Mouse, PLoS ONE. 8 (2013) e78262. https://doi.org/10.1371/journal.pone.0078262.

[82]C. Droin, J.E. Kholtei, K. Bahar Halpern, C. Hurni, M. Rozenberg, S. Muvkadi, S. Itzkovitz, F. Naef, Space-time logic of liver gene expression at sub-lobular scale, Nat. Metab. (2021). https://doi.org/10.1038/s42255-020-00323-1.

[83]J. Chen, J. Chen, H. Fu, Y. Li, L. Wang, S. Luo, H. Lu, Hypoxia exacerbates nonalcoholic fatty liver disease via the HIF-2a/PPARa pathway, Am. J. Physiol. Endocrinol. Metab. 317 (2019) E710-E722. https://doi.org/10.1152/ajpendo.00052.2019.

[84]J.A. Horscroft, K.A. O'Brien, A.D. Clark, R.T. Lindsay, A.S. Steel, N.E.K. Procter, J. Devaux, M. Frenneaux, S.D.R. Harridge, A.J. Murray, Inorganic nitrate, hypoxia, and the regulation of cardiac mitochondrial respiration-probing the role of PPAR , FASEB J. Off. Publ. Fed. Am. Soc. Exp. Biol. 33 (2019) 7563-7577. https://doi.org/10.1096/fj.201900067R.

[85]T.S. Simonson, Y. Yang, C.D. Huff, H. Yun, G. Qin, D.J. Witherspoon, Z. Bai, F.R. Lorenzo, J. Xing, L.B. Jorde, J.T. Prchal, R. Ge, Genetic evidence for high-altitude adaptation in Tibet, Science. 329 (2010) 72-75. https://doi.org/10.1126/science.1189406.

[86]J.L. Boyer, Bile Formation and Secretion, in: R. Terjung (Ed.), Compr. Physiol., John Wiley \& Sons, Inc., Hoboken, NJ, USA, 2013: p. c120027. http://doi.wiley.com/10.1002/cphy.c120027 (accessed April 23, 2020).

[87]F. Li, A.D. Patterson, K.W. Krausz, N. Tanaka, F.J. Gonzalez, Metabolomics reveals an essential role for peroxisome proliferator-activated receptor $\alpha$ in bile acid homeostasis, J. Lipid Res. 53 (2012) 1625-1635. https://doi.org/10.1194/jlr.M027433.

[88]S.M. Post, H. Duez, P.P. Gervois, B. Staels, F. Kuipers, H.M.G. Princen, Fibrates Suppress Bile Acid Synthesis via Peroxisome Proliferator-Activated Receptor-a-Mediated Downregulation of Cholesterol 7a-Hydroxylase and Sterol 27-Hydroxylase Expression, Arterioscler. Thromb. Vasc. Biol. 21 (2001) 1840-1845. https://doi.org/10.1161/hq1101.098228.

[89]C. Xie, S. Takahashi, C.N. Brocker, S. He, L. Chen, G. Xie, K. Jang, X. Gao, K.W. Krausz, A. Qu, M. Levi, F.J. Gonzalez, Hepatocyte peroxisome proliferator-activated receptor a regulates bile acid synthesis and transport, Biochim. Biophys. Acta BBA - Mol. Cell Biol. Lipids. 1864 (2019) 1396-1411. https://doi.org/10.1016/j.bbalip.2019.05.014. 
[90]N.S. Ghonem, D.N. Assis, J.L. Boyer, Fibrates and cholestasis, Hepatol. Baltim. Md. 62 (2015) 635-643. https://doi.org/10.1002/hep.27744.

[91]D. Jones, P.F. Boudes, M.G. Swain, C.L. Bowlus, M.R. Galambos, B.R. Bacon, Y. Doerffel, N. Gitlin, S.C. Gordon, J.A. Odin, D. Sheridan, M.-A. Wörns, V. Clark, L. Corless, H. Hartmann, M.E. Jonas, A.E. Kremer, G.F. Mells, P. Buggisch, B.L. Freilich, C. Levy, J.M. Vierling, D.E. Bernstein, M. Hartleb, E. Janczewska, F. Rochling, H. Shah, M.L. Shiffman, J.H. Smith, Y.-J. Choi, A. Steinberg, M. Varga, H. Chera, R. Martin, C.A. McWherter, G.M. Hirschfield, Seladelpar (MBX-8025), a selective PPAR- $\delta$ agonist, in patients with primary biliary cholangitis with an inadequate response to ursodeoxycholic acid: a double-blind, randomised, placebo-controlled, phase 2, proof-of-concept study, Lancet Gastroenterol. Hepatol. 2 (2017) 716-726. https://doi.org/10.1016/S2468-1253(17)30246-7.

[92]C. Corpechot, O. Chazouillères, A. Rousseau, A. Le Gruyer, F. Habersetzer, P. Mathurin, O. Goria, P. Potier, A. Minello, C. Silvain, A. Abergel, M. Debette-Gratien, D. Larrey, O. Roux, J.-P. Bronowicki, J. Boursier, V. de Ledinghen, A. Heurgue-Berlot, E. Nguyen-Khac, F. Zoulim, I. Ollivier-Hourmand, J.-P. Zarski, G. Nkontchou, S. Lemoinne, L. Humbert, D. Rainteau, G. Lefèvre, L. de Chaisemartin, S. Chollet-Martin, F. Gaouar, F.-H. Admane, T. Simon, R. Poupon, A Placebo-Controlled Trial of Bezafibrate in Primary Biliary Cholangitis, N. Engl. J. Med. 378 (2018) 2171-2181. https://doi.org/10.1056/NEJMoa1714519.

[93]A.F. Gulamhusein, G.M. Hirschfield, Primary biliary cholangitis: pathogenesis and therapeutic opportunities, Nat. Rev. Gastroenterol. Hepatol. 17 (2020) 93-110. https://doi.org/10.1038/s41575-019-0226-7.

[94]R.A. Shah, K.V. Kowdley, Current and potential treatments for primary biliary cholangitis, Lancet Gastroenterol. Hepatol. 5 (2020) 306-315. https://doi.org/10.1016/S24681253(19)30343-7.

[95]B. Wang, L. Zhao, M. Fish, C.Y. Logan, R. Nusse, Self-renewing diploid Axin2+ cells fuel homeostatic renewal of the liver, Nature. 524 (2015) 180-185. https://doi.org/10.1038/nature14863.

[96]W. Huang, Nuclear Receptor-Dependent Bile Acid Signaling Is Required for Normal Liver Regeneration, Science. 312 (2006) 233-236. https://doi.org/10.1126/science.1121435.

[97]W. Pu, H. Zhang, X. Huang, X. Tian, L. He, Y. Wang, L. Zhang, Q. Liu, Y. Li, Y. Li, H. Zhao, K. Liu, J. Lu, Y. Zhou, P. Huang, Y. Nie, Y. Yan, L. Hui, K.O. Lui, B. Zhou, Mfsd2a+ hepatocytes repopulate the liver during injury and regeneration, Nat. Commun. 7 (2016) 13369. https://doi.org/10.1038/ncomms13369.

[98]J. Lengqvist, A. Mata De Urquiza, A.-C. Bergman, T.M. Willson, J. Sjövall, T. Perlmann, W.J. Griffiths, Polyunsaturated fatty acids including docosahexaenoic and arachidonic acid bind to the retinoid $X$ receptor alpha ligand-binding domain, Mol. Cell. Proteomics MCP. 3 (2004) 692-703. https://doi.org/10.1074/mcp.M400003-MCP200.

[99]H. Keller, C. Dreyer, J. Medin, A. Mahfoudi, K. Ozato, W. Wahli, Fatty acids and retinoids control lipid metabolism through activation of peroxisome proliferator-activated receptorretinoid X receptor heterodimers, Proc. Natl. Acad. Sci. U. S. A. 90 (1993) 2160-2164. https://doi.org/10.1073/pnas.90.6.2160.

[100] Q. Lin, S.E. Ruuska, N.S. Shaw, D. Dong, N. Noy, Ligand selectivity of the peroxisome proliferator-activated receptor alpha, Biochemistry. 38 (1999) 185-190. https://doi.org/10.1021/bi9816094.

[101] M. Brosch, K. Kattler, A. Herrmann, W. von Schönfels, K. Nordström, D. Seehofer, G. Damm, T. Becker, S. Zeissig, S. Nehring, F. Reichel, V. Moser, R.V. Thangapandi, F. Stickel, G. Baretton, C. Röcken, M. Muders, M. Matz-Soja, M. Krawczak, G. Gasparoni, H. Hartmann, A. Dahl, C. Schafmayer, J. Walter, J. Hampe, Epigenomic map of human liver reveals principles of zonated morphogenic and metabolic control, Nat. Commun. 9 (2018) 4150. https://doi.org/10.1038/s41467-018-06611-5.

[102] S. Panda, Circadian physiology of metabolism, Science. 354 (2016) 1008-1015. https://doi.org/10.1126/science.aah4967.

[103] H. Reinke, G. Asher, Circadian Clock Control of Liver Metabolic Functions, Gastroenterology. 150 (2016) 574-580. https://doi.org/10.1053/j.gastro.2015.11.043. 
[104] H. Li, S. Zhang, W. Zhang, S. Chen, A. Rabearivony, Y. Shi, J. Liu, C.J. Corton, C. Liu, Endogenous circadian time genes expressions in the liver of mice under constant darkness, BMC Genomics. 21 (2020) 224. https://doi.org/10.1186/s12864-020-6639-4.

[105] A. Mukherji, A. Kobiita, P. Chambon, Shifting the feeding of mice to the rest phase creates metabolic alterations, which, on their own, shift the peripheral circadian clocks by 12 hours, Proc. Natl. Acad. Sci. 112 (2015) E6683-E6690. https://doi.org/10.1073/pnas.1519735112.

[106] A. Mukherji, S.M. Bailey, B. Staels, T.F. Baumert, The circadian clock and liver function in health and disease, J. Hepatol. 71 (2019) 200-211. https://doi.org/10.1016/j.jhep.2019.03.020.

[107] A. Chaix, T. Lin, H.D. Le, M.W. Chang, S. Panda, Time-Restricted Feeding Prevents Obesity and Metabolic Syndrome in Mice Lacking a Circadian Clock, Cell Metab. 29 (2019) 303-319.e4. https://doi.org/10.1016/j.cmet.2018.08.004.

[108] M. Hatori, C. Vollmers, A. Zarrinpar, L. DiTacchio, E.A. Bushong, S. Gill, M. Leblanc, A. Chaix, M. Joens, J.A.J. Fitzpatrick, M.H. Ellisman, S. Panda, Time-restricted feeding without reducing caloric intake prevents metabolic diseases in mice fed a high-fat diet, Cell Metab. 15 (2012) 848-860. https://doi.org/10.1016/j.cmet.2012.04.019.

[109] J.J. Gooley, E.C.-P. Chua, Diurnal regulation of lipid metabolism and applications of circadian lipidomics, J. Genet. Genomics Yi Chuan Xue Bao. 41 (2014) 231-250. https://doi.org/10.1016/j.jgg.2014.04.001.

[110] C.B. Peek, K.M. Ramsey, B. Marcheva, J. Bass, Nutrient sensing and the circadian clock, Trends Endocrinol. Metab. TEM. 23 (2012) 312-318. https://doi.org/10.1016/j.tem.2012.02.003.

[111] M. Murakami, P. Tognini, Y. Liu, K.L. Eckel-Mahan, P. Baldi, P. Sassone-Corsi, Gut microbiota directs PPARY-driven reprogramming of the liver circadian clock by nutritional challenge, EMBO Rep. 17 (2016) 1292-1303. https://doi.org/10.15252/embr.201642463.

[112] T. Lemberger, R. Saladin, M. Vázquez, F. Assimacopoulos, B. Staels, B. Desvergne, W. Wahli, J. Auwerx, Expression of the peroxisome proliferator-activated receptor alpha gene is stimulated by stress and follows a diurnal rhythm, J. Biol. Chem. 271 (1996) 17641769. https://doi.org/10.1074/jbc.271.3.1764.

[113] X. Yang, M. Downes, R.T. Yu, A.L. Bookout, W. He, M. Straume, D.J. Mangelsdorf, R.M. Evans, Nuclear receptor expression links the circadian clock to metabolism, Cell. 126 (2006) 801-810. https://doi.org/10.1016/j.cell.2006.06.050.

[114] I. Inoue, Y. Shinoda, M. Ikeda, K. Hayashi, K. Kanazawa, M. Nomura, T. Matsunaga, H. Xu, S. Kawai, T. Awata, T. Komoda, S. Katayama, CLOCK/BMAL1 is involved in lipid metabolism via transactivation of the peroxisome proliferator-activated receptor (PPAR) response element, J. Atheroscler. Thromb. 12 (2005) 169-174. https://doi.org/10.5551/jat.12.169.

[115] K. Oishi, H. Shirai, N. Ishida, CLOCK is involved in the circadian transactivation of peroxisome-proliferator-activated receptor alpha (PPARalpha) in mice, Biochem. J. 386 (2005) 575-581. https://doi.org/10.1042/BJ20041150.

[116] S. Takahashi, I. Inoue, Y. Nakajima, M. Seo, T. Nakano, F. Yang, M. Kumagai, T. Komoda, T. Awata, M. Ikeda, S. Katayama, A promoter in the novel exon of hPPARgamma directs the circadian expression of PPARgamma, J. Atheroscler. Thromb. 17 (2010) 7383. https://doi.org/10.5551/jat.2410.

[117] I. Schmutz, J.A. Ripperger, S. Baeriswyl-Aebischer, U. Albrecht, The mammalian clock component PERIOD2 coordinates circadian output by interaction with nuclear receptors, Genes Dev. 24 (2010) 345-357. https://doi.org/10.1101/gad.564110.

[118] S.D. Jordan, A. Kriebs, M. Vaughan, D. Duglan, W. Fan, E. Henriksson, A.-L. Huber, S.J. Papp, M. Nguyen, M. Afetian, M. Downes, R.T. Yu, A. Kralli, R.M. Evans, K.A. Lamia, CRY1/2 Selectively Repress PPARס and Limit Exercise Capacity, Cell Metab. 26 (2017) 243-255.e6. https://doi.org/10.1016/j.cmet.2017.06.002.

[119] L. Canaple, J. Rambaud, O. Dkhissi-Benyahya, B. Rayet, N.S. Tan, L. Michalik, F. Delaunay, W. Wahli, V. Laudet, Reciprocal regulation of brain and muscle Arnt-like protein 1 and peroxisome proliferator-activated receptor alpha defines a novel positive feedback 
loop in the rodent liver circadian clock, Mol. Endocrinol. Baltim. Md. 20 (2006) 1715-1727. https://doi.org/10.1210/me.2006-0052.

[120] N. Wang, G. Yang, Z. Jia, H. Zhang, T. Aoyagi, S. Soodvilai, J.D. Symons, J.B. Schnermann, F.J. Gonzalez, S.E. Litwin, T. Yang, Vascular PPARgamma controls circadian variation in blood pressure and heart rate through Bmal1, Cell Metab. 8 (2008) 482-491. https://doi.org/10.1016/j.cmet.2008.10.009.

[121] S.M. Lee, Y. Zhang, H. Tsuchiya, R. Smalling, A.M. Jetten, L. Wang, Small heterodimer partner/neuronal PAS domain protein 2 axis regulates the oscillation of liver lipid metabolism, Hepatol. Baltim. Md. 61 (2015) 497-505. https://doi.org/10.1002/hep.27437.

[122] P. Gervois, S. Chopin-Delannoy, A. Fadel, G. Dubois, V. Kosykh, J.C. Fruchart, J. Najïb, V. Laudet, B. Staels, Fibrates increase human REV-ERBalpha expression in liver via a novel peroxisome proliferator-activated receptor response element, Mol. Endocrinol. Baltim. Md. 13 (1999) 400-409. https://doi.org/10.1210/mend.13.3.0248.

[123] A. Kassam, J.P. Capone, R.A. Rachubinski, Orphan nuclear hormone receptor RevErbalpha modulates expression from the promoter of the hydratase-dehydrogenase gene by inhibiting peroxisome proliferator-activated receptor alpha-dependent transactivation, J. Biol. Chem. $274 \quad$ (1999) 22895-22900. https://doi.org/10.1074/jbc.274.32.22895.

[124] R. Gutman, M. Barnea, L. Haviv, N. Chapnik, O. Froy, Peroxisome proliferatoractivated receptor a (PPAR $\alpha$ ) activation advances locomotor activity and feeding daily rhythms in mice, Int. J. Obes. 2005. 36 (2012) 1131-1134. https://doi.org/10.1038/ijo.2011.215.

[125] P. Chen, X. Kakan, J. Zhang, Altered circadian rhythm of the clock genes in fibrotic livers induced by carbon tetrachloride, FEBS Lett. 584 (2010) 1597-1601. https://doi.org/10.1016/j.febslet.2010.03.019.

[126] G. Yang, Z. Jia, T. Aoyagi, D. McClain, R.M. Mortensen, T. Yang, Systemic PPARY deletion impairs circadian rhythms of behavior and metabolism, PloS One. 7 (2012) e38117. https://doi.org/10.1371/journal.pone.0038117.

[127] R. Brunmeir, F. Xu, Functional Regulation of PPARs through Post-Translational Modifications, Int. J. Mol. Sci. 19 (2018). https://doi.org/10.3390/ijms19061738.

[128] S.D. Jordan, K.A. Lamia, AMPK at the crossroads of circadian clocks and metabolism, Mol. Cell. Endocrinol. 366 (2013) 163-169. https://doi.org/10.1016/j.mce.2012.06.017.

[129] T. Leff, AMP-activated protein kinase regulates gene expression by direct phosphorylation of nuclear proteins, Biochem. Soc. Trans. 31 (2003) 224-227. https://doi.org/10.1042/bst0310224.

[130] K.A. Burns, J.P. Vanden Heuvel, Modulation of PPAR activity via phosphorylation, Biochim. Biophys. $\quad$ Acta. 1771 (2007) 952-960. https://doi.org/10.1016/j.bbalip.2007.04.018.

[131] M.S. Sozio, C. Lu, Y. Zeng, S. Liangpunsakul, D.W. Crabb, Activated AMPK inhibits PPAR-\{alpha\} and PPAR-\{gamma\} transcriptional activity in hepatoma cells, Am. J. Physiol. Gastrointest. Liver Physiol. $301 \quad$ (2011) G739-747. https://doi.org/10.1152/ajpgi.00432.2010.

[132] D. Ratman, V. Mylka, N. Bougarne, M. Pawlak, S. Caron, N. Hennuyer, R. Paumelle, L. De Cauwer, J. Thommis, M.H. Rider, C. Libert, S. Lievens, J. Tavernier, B. Staels, K. De Bosscher, Chromatin recruitment of activated AMPK drives fasting response genes cocontrolled by GR and PPARa, Nucleic Acids Res. 44 (2016) 10539-10553. https://doi.org/10.1093/nar/gkw742.

[133] W.H. Lee, S.G. Kim, AMPK-Dependent Metabolic Regulation by PPAR Agonists, PPAR Res. 2010 (2010). https://doi.org/10.1155/2010/549101.

[134] R. Marcos, C. Lopes, F. Malhão, C. Correia-Gomes, S. Fonseca, M. Lima, R. Gebhardt, E. Rocha, Stereological assessment of sexual dimorphism in the rat liver reveals differences in hepatocytes and Kupffer cells but not hepatic stellate cells, J. Anat. 228 (2016) 996-1005. https://doi.org/10.1111/joa.12448. 
[135] N. Bazhan, T. Jakovleva, N. Feofanova, E. Denisova, A. Dubinina, N. Sitnikova, E. Makarova, Sex Differences in Liver, Adipose Tissue, and Muscle Transcriptional Response to Fasting and Refeeding in Mice, Cells. 8 (2019). https://doi.org/10.3390/cells8121529.

[136] R. Marcos, C. Correia-Gomes, H. Miranda, F. Carneiro, Liver gender dimorphism-insights from quantitative morphology, Histol. Histopathol. 30 (2015) 1431-1437. https://doi.org/10.14670/HH-11-648.

[137] X. Yang, E.E. Schadt, S. Wang, H. Wang, A.P. Arnold, L. Ingram-Drake, T.A. Drake, A.J. Lusis, Tissue-specific expression and regulation of sexually dimorphic genes in mice, Genome Res. 16 (2006) 995-1004. https://doi.org/10.1101/gr.5217506.

[138] G. Rando, W. Wahli, Sex differences in nuclear receptor-regulated liver metabolic pathways, Biochim. Biophys. Acta. $1812 \quad$ (2011) 964-973. https://doi.org/10.1016/j.bbadis.2010.12.023.

[139] M. Jalouli, L. Carlsson, C. Améen, D. Lindén, A. Ljungberg, L. Michalik, S. Edén, W. Wahli, J. Oscarsson, Sex difference in hepatic peroxisome proliferator-activated receptor alpha expression: influence of pituitary and gonadal hormones, Endocrinology. 144 (2003) 101-109. https://doi.org/10.1210/en.2002-220630.

[140] X. Yang, Y.-K.J. Zhang, N. Esterly, C.D. Klaassen, Y.-J.Y. Wan, Gender disparity of hepatic lipid homoeostasis regulated by the circadian clock, J. Biochem. (Tokyo). 145 (2009) 609-623. https://doi.org/10.1093/jb/mvp018.

[141] B.D. Weger, C. Gobet, J. Yeung, E. Martin, S. Jimenez, B. Betrisey, F. Foata, B. Berger, A. Balvay, A. Foussier, A. Charpagne, B. Boizet-Bonhoure, C.J. Chou, F. Naef, F. Gachon, The Mouse Microbiome Is Required for Sex-Specific Diurnal Rhythms of Gene Expression $\begin{array}{llll}\text { and Metabolism, } \quad \text { Cell } \quad \text { Metab. } 29 & \text { (2019) }\end{array}$ https://doi.org/10.1016/j.cmet.2018.09.023.

[142] N. Leuenberger, S. Pradervand, W. Wahli, Sumoylated PPARalpha mediates sexspecific gene repression and protects the liver from estrogen-induced toxicity in mice, J. Clin. Invest. 119 (2009) 3138-3148. https://doi.org/10.1172/JCI39019.

[143] C. Weigt, T. Hertrampf, F.M. Kluxen, U. Flenker, F. Hülsemann, K.H. Fritzemeier, P. Diel, Molecular effects of ER alpha- and beta-selective agonists on regulation of energy homeostasis in obese female Wistar rats, Mol. Cell. Endocrinol. 377 (2013) 147-158. https://doi.org/10.1016/j.mce.2013.07.007.

[144] N. Ceglia, Y. Liu, S. Chen, F. Agostinelli, K. Eckel-Mahan, P. Sassone-Corsi, P. Baldi, CircadiOmics: circadian omic web portal, Nucleic Acids Res. 46 (2018) W157-W162. https://doi.org/10.1093/nar/gky441.

[145] F. Agostinelli, N. Ceglia, B. Shahbaba, P. Sassone-Corsi, P. Baldi, What time is it? Deep learning approaches for circadian rhythms, Bioinforma. Oxf. Engl. 32 (2016) 3051. https://doi.org/10.1093/bioinformatics/btw504.

[146] V.R. Patel, K. Eckel-Mahan, P. Sassone-Corsi, P. Baldi, CircadiOmics: integrating circadian genomics, transcriptomics, proteomics and metabolomics, Nat. Methods. 9 (2012) 772-773. https://doi.org/10.1038/nmeth.2111.

[147] D. Kaltenecker, M. Themanns, K.M. Mueller, K. Spirk, T. Suske, O. Merkel, L. Kenner, A. Luís, A. Kozlov, J. Haybaeck, M. Müller, X. Han, R. Moriggl, Hepatic growth hormone JAK2 - STAT5 signalling: Metabolic function, non-alcoholic fatty liver disease and hepatocellular carcinoma progression, Cytokine. $124 \quad$ (2019) 154569. https://doi.org/10.1016/j.cyto.2018.10.010.

[148] J. Korbecki, R. Bobiński, M. Dutka, Self-regulation of the inflammatory response by peroxisome proliferator-activated receptors, Inflamm. Res. Off. J. Eur. Histamine Res. Soc. Al. 68 (2019) 443-458. https://doi.org/10.1007/s00011-019-01231-1.

[149] M.V. Chakravarthy, Z. Pan, Y. Zhu, K. Tordjman, J.G. Schneider, T. Coleman, J. Turk, C.F. Semenkovich, "New" hepatic fat activates PPARalpha to maintain glucose, lipid, and cholesterol homeostasis, Cell Metab. 1 (2005) 309-322. https://doi.org/10.1016/j.cmet.2005.04.002.

[150] M.V. Chakravarthy, I.J. Lodhi, L. Yin, R.R.V. Malapaka, H.E. Xu, J. Turk, C.F. Semenkovich, Identification of a physiologically relevant endogenous ligand for PPARalpha in liver, Cell. 138 (2009) 476-488. https://doi.org/10.1016/j.cell.2009.05.036. 
[151] T. Yamauchi, Y. Nio, T. Maki, M. Kobayashi, T. Takazawa, M. Iwabu, M. Okada-Iwabu, S. Kawamoto, N. Kubota, T. Kubota, Y. Ito, J. Kamon, A. Tsuchida, K. Kumagai, H. Kozono, Y. Hada, H. Ogata, K. Tokuyama, M. Tsunoda, T. Ide, K. Murakami, M. Awazawa, I. Takamoto, P. Froguel, K. Hara, K. Tobe, R. Nagai, K. Ueki, T. Kadowaki, Targeted disruption of AdipoR1 and AdipoR2 causes abrogation of adiponectin binding and metabolic actions, Nat. Med. 13 (2007) 332-339. https://doi.org/10.1038/nm1557.

[152] H. Tanabe, Y. Fujii, M. Okada-Iwabu, M. Iwabu, Y. Nakamura, T. Hosaka, K. Motoyama, M. Ikeda, M. Wakiyama, T. Terada, N. Ohsawa, M. Hato, S. Ogasawara, T. Hino, T. Murata, S. Iwata, K. Hirata, Y. Kawano, M. Yamamoto, T. Kimura-Someya, M. Shirouzu, T. Yamauchi, T. Kadowaki, S. Yokoyama, Crystal structures of the human adiponectin receptors, Nature. 520 (2015) 312-316. https://doi.org/10.1038/nature14301.

[153] A.X. Sharma, W.L. Holland, Adiponectin and its Hydrolase-Activated Receptors, J. Nat. Sci. 3 (2017).

[154] J.B. Kim, H.M. Wright, M. Wright, B.M. Spiegelman, ADD1/SREBP1 activates PPARgamma through the production of endogenous ligand, Proc. Natl. Acad. Sci. U. S. A. 95 (1998) 4333-4337. https://doi.org/10.1073/pnas.95.8.4333.

[155] S.A. Kliewer, J.M. Lenhard, T.M. Willson, I. Patel, D.C. Morris, J.M. Lehmann, A prostaglandin $\mathrm{J} 2$ metabolite binds peroxisome proliferator-activated receptor gamma and promotes adipocyte differentiation, Cell. 83 (1995) 813-819. https://doi.org/10.1016/00928674(95)90194-9.

[156] W.S. Powell, 15-Deoxy-delta12,14-PGJ2: endogenous PPARgamma ligand or minor eicosanoid degradation product?, J. Clin. Invest. 112 (2003) 828-830. https://doi.org/10.1172/JCl19796.

[157] M. Schupp, M.A. Lazar, Endogenous ligands for nuclear receptors: digging deeper, J. Biol. Chem. 285 (2010) 40409-40415. https://doi.org/10.1074/jbc.R110.182451.

[158] H.E. Xu, M.H. Lambert, V.G. Montana, D.J. Parks, S.G. Blanchard, P.J. Brown, D.D. Sternbach, J.M. Lehmann, G.B. Wisely, T.M. Willson, S.A. Kliewer, M.V. Milburn, Molecular recognition of fatty acids by peroxisome proliferator-activated receptors, Mol. Cell. 3 (1999) 397-403. https://doi.org/10.1016/s1097-2765(00)80467-0.

[159] Y. Liu, J.K. Colby, X. Zuo, J. Jaoude, D. Wei, I. Shureiqi, The Role of PPAR-ס in Metabolism, Inflammation, and Cancer: Many Characters of a Critical Transcription Factor, Int. J. Mol. Sci. 19 (2018). https://doi.org/10.3390/ijms19113339.

[160] S. Kersten, R. Stienstra, The role and regulation of the peroxisome proliferator activated receptor alpha in human liver, Biochimie. 136 (2017) 75-84. https://doi.org/10.1016/j.biochi.2016.12.019.

[161] D.P. Oswal, M. Balanarasimha, J.K. Loyer, S. Bedi, F.L. Soman, S.D. Rider, H.A. Hostetler, Divergence between human and murine peroxisome proliferator-activated receptor alpha ligand specificities, J. Lipid Res. 54 (2013) 2354-2365. https://doi.org/10.1194/jlr.M035436.

[162] S. Naruhn, W. Meissner, T. Adhikary, K. Kaddatz, T. Klein, B. Watzer, S. MüllerBrüsselbach, R. Müller, 15-hydroxyeicosatetraenoic acid is a preferential peroxisome proliferator-activated receptor beta/delta agonist, Mol. Pharmacol. 77 (2010) 171-184. https://doi.org/10.1124/mol.109.060541.

[163] J.-M. Ye, J. Tid-Ang, N. Turner, X.-Y. Zeng, H.-Y. Li, G.J. Cooney, E.M. Wulff, P. Sauerberg, E.W. Kraegen, PPARס agonists have opposing effects on insulin resistance in high fat-fed rats and mice due to different metabolic responses in muscle, Br. J. Pharmacol. 163 (2011) 556-566. https://doi.org/10.1111/j.1476-5381.2011.01240.x.

[164] B. Da'adoosh, D. Marcus, A. Rayan, F. King, J. Che, A. Goldblum, Discovering highly selective and diverse PPAR-delta agonists by ligand based machine learning and structural modeling, Sci. Rep. 9 (2019) 1106. https://doi.org/10.1038/s41598-019-385088.

[165] A. Sahebkar, G.T. Chew, G.F. Watts, New peroxisome proliferator-activated receptor agonists: potential treatments for atherogenic dyslipidemia and non-alcoholic fatty liver disease, Expert Opin. Pharmacother. $15 \quad$ (2014) 493-503. https://doi.org/10.1517/14656566.2014.876992. 
[166] A. Sapone, J.M. Peters, S. Sakai, S. Tomita, S.S. Papiha, R. Dai, F.K. Friedman, F.J. Gonzalez, The human peroxisome proliferator-activated receptor ?? gene: identification and functional characterization of two natural allelic variants:, Pharmacogenetics. 10 (2000) 321-333. https://doi.org/10.1097/00008571-200006000-00006.

[167] E.S. Tai, D. Corella, S. Demissie, L.A. Cupples, O. Coltell, E.J. Schaefer, K.L. Tucker, J.M. Ordovas, Framingham heart study, Polyunsaturated fatty acids interact with the PPARA-L162V polymorphism to affect plasma triglyceride and apolipoprotein C-III concentrations in the Framingham Heart Study, J. Nutr. 135 (2005) 397-403. https://doi.org/10.1093/jn/135.3.397.

[168] S. Heikkinen, J. Auwerx, C.A. Argmann, PPARgamma in human and mouse physiology, Biochim. Biophys. Acta. 1771 (2007) 999-1013. https://doi.org/10.1016/j.bbalip.2007.03.006. 


\begin{tabular}{|c|c|c|c|c|c|c|c|c|}
\hline \multirow{2}{*}{ Agonist } & \multirow{2}{*}{ Structure } & \multicolumn{3}{|c|}{ Isotype selectivity } & \multirow{2}{*}{$\begin{array}{c}\text { Serological } \\
\text { effects }\end{array}$} & \multirow{2}{*}{$\begin{array}{l}\text { Improvement of } \\
\text { NAFLD? }\end{array}$} & \multirow{2}{*}{ Clinical trials for NASH } & \multirow{2}{*}{ Clinical trials for other Pathologies } \\
\hline & & PPAR $\alpha$ & PPAR $\beta / \delta$ & PPARY & & & & \\
\hline Pemafibrate & & $\sqrt{ }$ & & & $\begin{array}{l}\searrow \text { FFA } \\
\searrow \text { Plasma TG } \\
\nearrow \text { HDL-C }\end{array}$ & Unknown & $\begin{array}{c}\text { Phase II } \\
\text { NCT03350165, active }\end{array}$ & $\begin{array}{l}\text { T2D, dyslipidemia: NCT03071692 (phase III), active } \\
\text { T2D, retinopathy: NCTO3345901 (phase III), terminated } \\
\text { Dyslipidemia: NCT04079530 (phase II), active }\end{array}$ \\
\hline Fenofibrate & & $\sqrt{ }$ & & & $\begin{array}{l}\searrow \text { FFA } \\
\searrow \text { Plasma TG } \\
\nearrow \text { HDL-C }\end{array}$ & No effect & $\begin{array}{c}\text { Phase II } \\
\text { NCT02781584, active } \\
\text { NCT02354976, completed }\end{array}$ & $\begin{array}{c}\text { PBC : NCT00575042 (phase II), completed } \\
\text { PBC: NCT02823353 and NCT02823366 (phase III), } \\
\text { status unknown } \\
\text { T2D, dyslipidemia, cardiovascular disease, ... several } \\
\text { trials up to stage IV }\end{array}$ \\
\hline Bezafibrate & & $\sqrt{ }$ & $\sqrt{ }$ & $\sqrt{ }$ & $\begin{array}{l}\searrow \text { FFA } \\
\searrow \text { Plasma TG } \\
\nearrow \text { HDL-C }\end{array}$ & Unknown & None to date & $\begin{array}{l}\text { PBC : NCT01654731 (phase III), completed } \\
\text { PBC: NCT02937012 (phase III), unknown } \\
\text { PBC: NCT02701166 (phase III), unknown } \\
\text { PBC: NCT04594694 (phase II), recruiting } \\
\text { AMI, LMSDM, ACS, HCL... up to stage IV }\end{array}$ \\
\hline Pioglitazone & & $v$ & & V & $\begin{array}{l}\searrow \text { FFA } \\
\searrow \text { Plasma TG } \\
\nearrow \text { HDL-C } \\
\searrow \text { Glycemia }\end{array}$ & Resolution of NASH & $\begin{array}{l}\text { Phase II } \\
\text { NCT009g4682 and others, } \\
\text { completed }\end{array}$ & $\begin{array}{l}\text { Cirrhosis: NCT00570622 (phase IV), completed } \\
\text { HepB-fibrosis: NCT04584242 (phase IV), recruiting } \\
\text { Many others: } 51 \text { finished/active/recruiting studies }\end{array}$ \\
\hline Saroglitazar & & V & & $v$ & $\begin{array}{l}\searrow \text { FFA } \\
\searrow \text { Plasma TG } \\
\nearrow \text { HDL-C } \\
\searrow \text { Glycemia }\end{array}$ & $\begin{array}{l}\searrow \text { Hepatosteatosis } \\
\searrow \text { ALT }\end{array}$ & $\begin{array}{c}\text { Phase II } \\
\text { NCT03061721, completed } \\
\text { NCT03863574, completed }\end{array}$ & $\begin{array}{l}\text { PBC: NCT03112681 (phase II), completed } \\
\text { Dyslipidemia: CTRI/2009/091/000527 (Phase III, } \\
\text { completed) } \\
\text { Renal impairment: NCT04446507 (phase I), recruiting }\end{array}$ \\
\hline Elafibranor & & V & $v$ & & $\begin{array}{l}\searrow \text { FFA } \\
\searrow \text { Plasma TG } \\
\nearrow \text { HDL-C } \\
\searrow \text { Glycemia }\end{array}$ & No effect & $\begin{array}{c}\text { Phase III } \\
\text { NCT02704403, terminated } \\
\text { Phase II } \\
\text { NCT03883607, terminated } \\
\text { NCT03953456, terminated }\end{array}$ & $\begin{array}{c}\text { PBC: NCT04526665 (phase III), recruiting } \\
\text { PBC: NCT03124108 (phase II), completed } \\
\text { Renal impairment: NCT03844555 (phase I), completed }\end{array}$ \\
\hline Lanifibranor & & $\checkmark$ & $v$ & v & $\begin{array}{l}\searrow \text { FFA } \\
\searrow \text { Plasma TG } \\
\nearrow \text { HDL-C } \\
\searrow \text { Glycemia }\end{array}$ & $\begin{array}{l}\text { Resolution of NASH } \\
\text { and fibrosis } \\
\quad \forall \text { ALT }\end{array}$ & $\begin{array}{c}\text { Phase III } \\
\text { NCT03459079, recruiting } \\
\text { NCT03008070, completed }\end{array}$ & $\begin{array}{l}\text { Scleroderma/DCSS : NCT02503644 (phase II), } \\
\text { completed }\end{array}$ \\
\hline Rosiglitazone & & & & $\sqrt{ }$ & $\begin{array}{l}\searrow \text { FFA } \\
\searrow \text { Glycemia } \\
\nearrow \text { HDL-C } \\
\nearrow \text { LDL-C }\end{array}$ & $\searrow$ Hepatosteatosis & $\begin{array}{c}\text { Phase II } \\
\text { NCT00492700 and others, } \\
\text { completed } \\
\text { Phase IV } \\
\text { NCT01406704, terminated }\end{array}$ & $\begin{array}{c}\mathrm{T} 2 \mathrm{D}, \mathrm{HepC}, \mathrm{CAD}, \mathrm{POS}, \ldots \text { many trials up to phase IV: } \\
\text { most completed/terminated } \\
\text { Many others in phase I-III: most completed/terminated }\end{array}$ \\
\hline Seladelpar & & & $\sqrt{ }$ & & $\begin{array}{l}\searrow \text { FFA } \\
\searrow \text { Plasma TG } \\
\nearrow \text { HDL-C } \searrow \text { LDL-C } \\
\searrow \text { Glycemia }\end{array}$ & Unclear & $\begin{array}{c}\text { Phase II } \\
\text { NCT03551522, suspended }\end{array}$ & $\begin{array}{l}\text { PBC: NCT03301506 (phase III), active } \\
\text { PBC: NCT03602560 (phase III), suspended } \\
\text { PBC: NCT02955602 (phase III, completed } \\
\text { PBC: NCTO2609048 (phase II), terminated } \\
\text { PSC: NCT04024813 (phase III), suspended }\end{array}$ \\
\hline
\end{tabular}


Table 1: PPAR agonists in clinical trials. The structure, relative affinity for PPAR isotypes and blood biochemical parameters at completion of the trial are indicated. Outcomes in NASH/fibrosis trials are indicated when known, and current evaluation in other liver pathologies are mentioned. Abbreviations used: T2D, type 2 diabetes; PBC, primary biliary cholangitis; DCSS, diffuse cutaneous systemic sclerosis; HepB, hepatitis B; HepC, hepatitis C; CAD, coronary artery disease; PCOS, polycystic ovary syndrome; AMI, acute myocardial infarction; NLSD, neutral lipid storage disease; ACS, acute coronary syndrome; HCL, hypercholesterolemia. Main source: https://clinicaltrials.gov/ 
Figures 


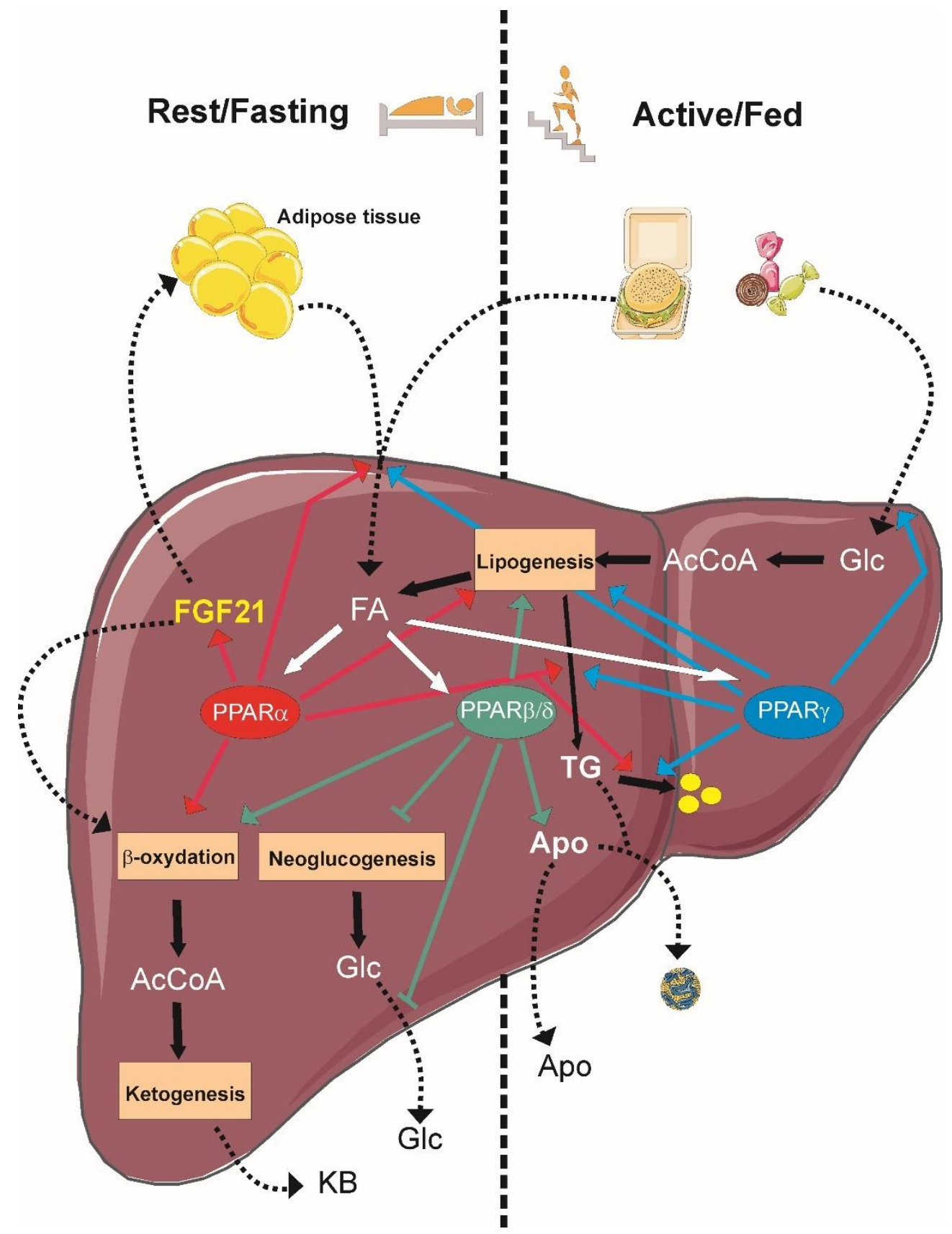

Figure 1: Regulation of hepatic metabolism by PPARs. During the rest period, the liver has to adapt its metabolic activities to the fasting state. PPAR $\alpha$, activated by fatty acids (FAs) from adipose tissue lipolysis, favors hepatic uptake of these FAs and energy production through $\beta$ oxidation. This metabolic pathway produces acetyl-CoA, which can either enter the TCA cycle or be used in ketogenesis. Hepatic PPAR $\alpha$ controls the adipose tissue-dependent release of FAs by inducing FGF21 expression, which has both endocrine and autocrine effects, inducing hepatic fatty acid oxidation. Activation of PPARס by FAs also enhances $\beta$-oxidation and represses hepatic glucose (Glc) production by reducing gluconeogenesis and glucose output, while directing glucose metabolites towards lipogenesis. Activated PPAR $\beta / \delta$ also induces the synthesis of apolipoproteins (mainly APO-All), increasing blood HDL-cholesterol levels. During the active period (fed state), the metabolic activities of the liver switch from energy production to energy storage and in this context, PPARy increases uptake of dietary FAs and glucose as well as lipogenesis, TG synthesis and storage. In parallel, PPARa induces hepatic lipogenesis allowing the storage of FAs as triglycerides. 


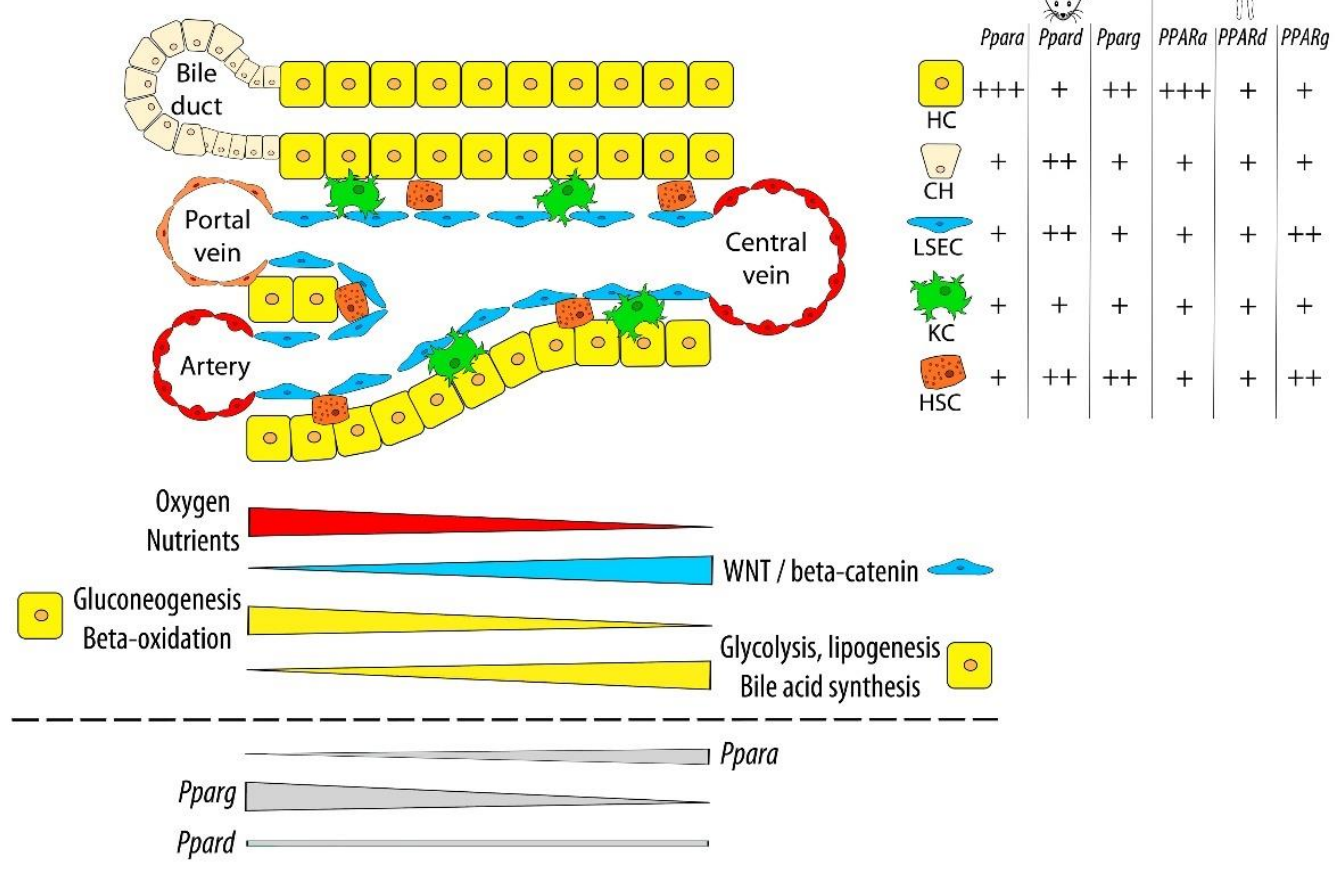

Figure 2: PPARs in liver cell types and zonation. Schematic representation of the liver structure. In the sinusoids blood enriched in oxygen and nutrients flows from the hepatic artery and the portal vein to the central vein. The major liver populations are shown: hepatocytes $(\mathrm{HC})$, cholangiocytes $(\mathrm{CH})$, liver sinusoidal endothelial cells (LSEC), Kupffer cells (KC) and hepatic stellate cells (HSC). PPAR expression levels in the different cell populations are reported for mice and men. Zonation is mainly caused by a gradient of oxygen, nutrients and WNT signaling and affects several metabolic activities. While Ppara is slightly more expressed in pericentral areas, Pparg is markedly periportal. Ppard expression does not appear to be zonated.

+++: highly expressed; ++: expressed; +: low or no expression. 


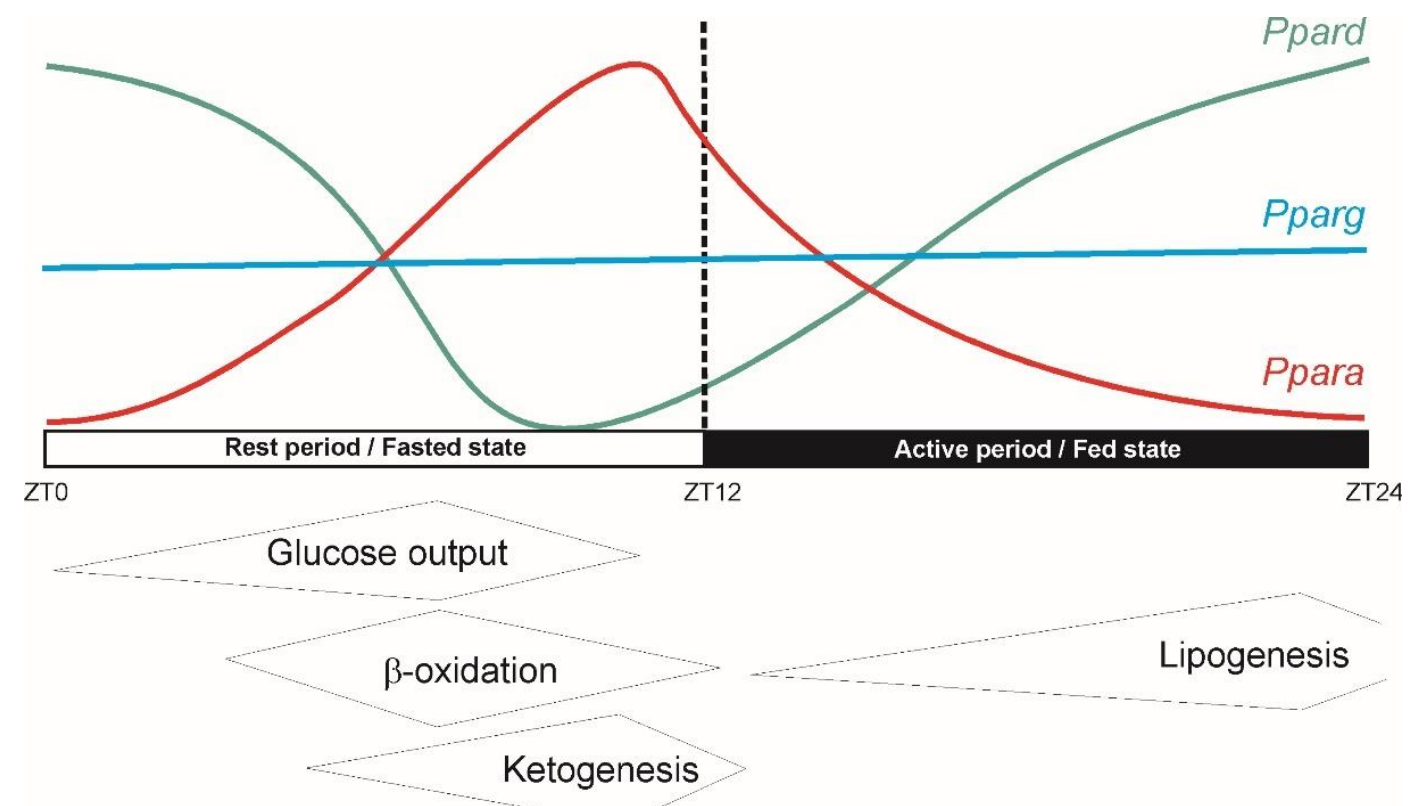

Figure 3: Circadian expression of PPAR isotypes. Hepatic Ppara and Ppard are expressed in a circadian manner contrary to Pparg, which exhibits a more stable expression around the day. Ppara expression is highest in mice during the second half of the rest period (fasted state) when hepatic metabolism shifts to energy production through hepatic glucose output, $\beta$ oxidation and ketogenesis. Conversely, Pparb/d expression peaks at the end of the active phase (fed state). 